This is the author accepted version of the manuscript for the following article:

Robertson, J., Baines, S., Emerson, E., \& Hatton, C. (2017). Constipation management in people with intellectual disability: A systematic review. Journal of Applied Research in Intellectual Disabilities, E-pub ahead of print, pp. 1-16. doi:10.1111/jar.12426. 


\title{
Constipation management in people with intellectual disability: a systematic review
}

\author{
Abstract \\ Background. Constipation can lead to serious health issues and death. This systematic review \\ summarises international research pertaining to the management of constipation in people \\ with intellectual disability. \\ Method. Studies published from 1990 to 2017 were identified using Medline, Cinahl, \\ PsycINFO, Web of Science, email requests, and cross-citations. Studies were reviewed \\ narratively in relation to identified themes. \\ Results. 18 studies were reviewed in relation to three themes: laxative receipt; interventions \\ (dietary fibre, abdominal massage and macrogol); and staff issues (knowledge and training). \\ Laxative polypharmacy was common. Studies report positive results for dietary fibre and \\ abdominal massage although study quality was limited. \\ Conclusion. The main management response to constipation in people with intellectual \\ disability is laxative use despite limited effectiveness. An improved evidence base is \\ required to support the suggestion that an individualised, integrated bowel management \\ programme may reduce constipation and associated health conditions in people with \\ intellectual disability.
}




\section{Introduction}

Constipation is a syndrome defined by bowel symptoms of difficult or infrequent passage of stool, hardness of stool, or a feeling of incomplete evacuation (Bharucha et al., 2013). Constipation can be classified as primary constipation (also referred to as chronic idiopathic constipation (CIC) or functional constipation) and secondary constipation (attributed to comorbid medical conditions or medications) (Sbahi and Cash, 2015).

The concept of constipation is complicated by disagreement among patients and doctors about its nature (Longstreth et al., 2006). Whilst physicians often regard constipation to be synonymous with infrequent bowel movements (usually less than three times a week), patients may have a broader set of symptoms, as while bowel movement infrequency can be distressing to patients it is the quality of, or difficulty associated with, defecation that is the primary determinant of patient-described constipation (Sbahi and Cash, 2015). As such, the Rome III diagnostic criteria for functional constipation (Longstreth et al., 2006) incorporates symptoms such as 'sensation of incomplete evacuation for at least $25 \%$ of defecations', and 'straining during at least $25 \%$ of defecations'.

The complications of chronic constipation can be serious and life-threatening, including: faecal incontinence (where overflow incontinence may confuse the diagnosis of chronic constipation); haemorrhoids; anal fissure; pelvic organ prolapse; faecal impaction and bowel obstruction necessitating surgery; and bowel perforation and stercoral peritonitis where extremely impacted faeces can compress the colonic wall, causing an ischemic ulcer and subsequent perforation, culminating in stercoral peritonitis and sometimes death (Leung et al., 2011, Serrano Falcón et al., 2016). Faecal impaction can also lead to megacolon (Serrano Falcón et al., 2016). Further, the impairment in health related quality of life (HRQoL) observed in adults with constipation is comparable with that seen in conditions that might be regarded as more 'serious', such as osteoarthritis, rheumatoid arthritis, chronic 
allergies and diabetes (Belsey et al., 2010). In children, the level of impairment seen is greater than with gastro-oesophageal reflux and inflammatory bowel disease (Belsey et al., 2010). Early detection and management are crucial (De Hert et al., 2011).

There are a number of reasons underlying a need to focus on constipation in people with intellectual disability. The usual trigger for doctors to consider constipation is the specific mention of constipation by the patient or the communicated history of abdominal symptoms, but patients with intellectual disability may be unable to communicate these (Coleman and Spurling, 2010). In people with intellectual disability, pain from constipation may present as distress, sleep disturbance or behavioural changes (Coleman and Spurling, 2010), and may be associated with behavioural problems such as aggression and self-injury (Bosch et al., 1997, Christensen et al., 2009, Carr and Smith, 1995). As a result, constipation may be missed.

Constipation can have serious consequences for people with intellectual disability if it is not identified and managed appropriately. Constipation constitutes an ambulatory care sensitive condition (ACSC) for people with intellectual disability (Balogh et al., 2011). A Canadian study on hospitalisation rates for ACSCs found that the hospitalisation rate for constipation for people with intellectual disability was 7.9 times higher (95\% CI 4.4, 14.2) than for people without an intellectual disability (Balogh et al., 2010). In England, constipation was found to be one of the common causes of emergency hospital admissions for ACSCs (Glover and Evison, 2013). Constipation can also lead to death. The Safeguarding Adults Board in Suffolk, England, commissioned two Serious Case Reviews in early 2014 into the deaths of two people with intellectual disability (Flynn and Eley, 2015b, Flynn and Eley, 2015c), both of whom died from complications arising from constipation (Flynn and Eley, 2015a). 
Several factors put people with intellectual disability at increased risk of constipation. Many medicines are constipating (NICE, 2015) and people with intellectual disability are more likely to be prescribed some of these. For example, constipation is a common side effect of different antipsychotics (De Hert et al., 2011) and people with intellectual disability are much more likely than others to be prescribed anti-psychotic medications (Glover et al., 2015). Progression from constipation to ileus, intestinal obstruction, bowel ischaemia, megacolon and death is not uncommon, particularly in patients (not necessarily with intellectual disability) prescribed clozapine (Every-Palmer et al., 2017). People with intellectual disability are also more likely to have poor diet (Humphries et al., 2009), physical mobility limitations (Cleaver et al., 2009), and low levels of physical activity (Emerson, 2005, Robertson et al., 2000), all factors associated with constipation (Mugie et al., 2011). People with Down syndrome are more likely to have hypothyroidism (Goday-Arno et al., 2009) which is associated with constipation (NICE, 2015).

This increased risk is reflected in findings of a high prevalence of constipation in people with intellectual disability. A recent systematic review on the prevalence of constipation in people with intellectual disability identified 31 relevant studies, of which 14 reported constipation rates of $50 \%$ or more, and 21 reported rates over 33\% (Robertson et al., 2017). Constipation was more common in those with cerebral palsy and profound intellectual disability, and associated with immobility but not age, suggesting that constipation is a significant issue for people with intellectual disability across the life course. In a further recent study, of 99 people with severe or profound intellectual and motor disabilities, 94\% had constipation (van Timmeren et al., 2016).

In view of the serious potential consequences of constipation and the high prevalence of constipation, there is a clear need to consider how services should respond in order to effectively manage constipation in people with intellectual disability. The aforementioned 
review included studies of laxative use as an indicator of constipation and it is clear that rates of laxative use are high and likely to constitute the predominant management response to constipation in this population. Based on the most representative study which included 868 people with intellectual disability and 4,305 controls, over $25 \%$ of people with intellectual disability received a repeat prescription for laxatives in one year, compared to $0.1 \%$ of people without intellectual disability (Straetmans et al., 2007). Of nearly 3,000 adults and children with Down syndrome, the one year prevalence of laxative prescription was $18.8 \%$ compared to $3.4 \%$ of 8,910 matched controls (Alexander et al., 2015). Of 254 people with profound intellectual and multiple disabilities, $65.0 \%$ had been prescribed laxatives in the previous year (van der Heide, van der Putten, van den Berg, Taxis, \& Vlaskamp, 2009). Other figures for laxative use included: $73.1 \%$ of 26 females with profound intellectual disability (Giesbers et al., 2012), 65\% of 55 institutionalized adults with profound intellectual disability (Kozma and Mason, 2003), 43.3\% of 806 people aged 50+ known to intellectual disability services (Hermans and Evenhuis, 2014), and $26.4 \%$ of 254 people with moderate to profound intellectual disability living in institutions (Van Winckel et al., 1999).

However, the reliance on laxatives as a management response may be inappropriate. Clinical trials show that most laxatives achieve poor results (Jiang et al., 2015). Many community-based patients (not necessarily with intellectual disability) have poorly controlled constipation despite receiving laxatives regularly, with complex, ineffective and/or inappropriate laxative prescribing linked to sub-optimal bowel care (Addison et al., 2003). Whilst further studies are required, there is also some evidence that long term laxative use may be linked to colorectal cancer (Watanabe et al., 2004), particularly with respect to nonfibre laxatives (Citronberg et al., 2014). There are also potential hazards of mineral oil use for chronic constipation in relation to lipoid pneumonia (Bandla et al., 1999). 
The objective of this paper is to present the first systematic review of international research pertaining to the management of constipation in people with intellectual disability. The review aims to summarise research on how constipation is currently managed, the effectiveness of interventions for constipation, and service related issues such as staff knowledge and training.

\section{Method}

The review was conducted in accordance with PRISMA guidelines (Moher et al., 2009). Electronic literature database searches were conducted in Medline, Cinahl and PsycINFO (all on EBSCO) and Web of Science (Core Collection) in January 2016 and subsequently updated on March $7^{\text {th }}$ 2017. Searches combined terms for constipation and intellectual disability with the Boolean operator 'and'. An example of database specific search terms (Medline) is given in Appendix One. Searches included broad terms relating to constipation and people with intellectual disability. Specific inclusion and exclusion criteria relating to constipation management were applied as below. The reference lists of studies meeting the inclusion criteria were searched. In addition, in December 2015 a request for information on research relevant to the review was sent to members of the International Association for the Scientific Study of Intellectual and Developmental Disabilities (IASSIDD) Health Special Interest Research Group and the Intellectual Disability UK Research mailing list.

\section{$\underline{\text { Inclusion Criteria }}$}

Articles were required to meet all the following criteria:

- Peer reviewed

- English language full text

- $\quad$ Published from 1990 to March $7^{\text {th }} 2017$

- Quantitative research, evaluation or audit, or qualitative research 
- Samples where $50 \%$ or more have intellectual disability or mixed samples where results are disaggregated for people with intellectual disability

- Includes data regarding the current management of constipation (including type of laxatives prescribed), intervention effectiveness, or service related issues such as staff training or knowledge of carers regarding constipation

\section{$\underline{\text { Exclusion Criteria }}$}

- Not peer reviewed or peer review status unclear

- Any study employing any research design with a sample size of less than 10

- Reviews, letters, commentaries, editorials, meeting or conference abstracts

- Studies based on neonates (new born infants up to 28 days after birth)

- Studies on conditions where intellectual disability cannot be assumed (e.g. cerebral palsy) where results not disaggregated for people with intellectual disability

- Studies on specific syndromes associated with intellectual disability with the exception of Down syndrome, which is the most common genetic cause of intellectual disability (Sherman et al., 2007). Less common specific syndromes such as Rett syndrome were excluded although it is evident that some research on such syndromes exists (e.g. Baikie et al., 2014, Schwartzman et al., 2008)

- Studies relating to medication as an intervention where use of the medication is not supported by current knowledge or constipation management guidelines (NICE, 2010, NICE, 2015).

- Studies only presenting information on the percentage of people with intellectual disability who receive laxative medication as this is covered in an existing review (Robertson et al., 2017)

- Studies relating to encopresis (soiling) 
- Studies relating to Hirschsprung's disease and Down syndrome, as a meta-analysis of 61 studies relating to incidence, outcomes and mortality already exists (Friedmacher and Puri, 2013).

Initially, titles and abstracts were used to exclude studies which were obviously not within scope (first author). Those retained for further screening were those for which relevance could not be assessed without accessing full text, or those that were chosen as potentially within scope. These studies were screened by the first and last author and discussed until consensus was reached on whether or not they met the inclusion criteria. All relevant studies were included in the review regardless of methodological quality. Study data was extracted from full text articles and entered into an excel database with regard to: authors, year, country, main focus of study, study design, sample source, key sample features, sample size, sample age range (mean, SD and median), sample living situation, percentage of sample male, measures employed, and management related results.

\section{Quality Assessment/Risk of Bias}

Study quality was assessed using the Mixed Methods Appraisal Tool (MMAT) which was designed for the appraisal stage of systematic reviews that include qualitative, quantitative and mixed method studies and allows reviewers to concomitantly appraise most common types of study methodology and design (Pluye et al., 2011). In the MMAT, primary studies (or mixed method study components) are rated in relation to four specific methodological quality criteria depending on study type: qualitative; quantitative randomized controlled (trials); quantitative non-randomized; or quantitative descriptive studies. The number of the criteria met is reported in the form of an asterix $\left(^{*}\right)$ for each criterion met. For quasi-experimental designs not employing a control group (scored using the criteria for quantitative non-randomized studies) a criterion relating to comparability of groups was not 
applicable hence these studies could not attain a score greater than $3 *$ out of $4 *$. The MMAT is an efficient tool, but reliability needs further improvement, particularly for two items relating to qualitative studies including the sentence 'appropriate consideration' (Souto et al., 2015).

\section{Identification of Themes}

An iterative approach was taken in which a list of themes was identified by the first author via reading and re-reading the study summaries in Excel and these themes were allocated to overarching themes (Braun and Clarke, 2006). The themes and overarching themes identified were entered into the Excel database for each study. These were then checked by the last author and discussed until consensus was reached. Results were collated, summarised and reported via a tabulation of key data, descriptive numerical summary of included studies (e.g. number with particular research designs) and a descriptive narrative summary of the identified themes.

All extracted data in Excel was subsequently checked for accuracy and completeness by the last author. MMAT ratings and theme allocation were also checked by the last author. Whilst a third reviewer was available to resolve any disagreements, no instances of disagreement arose.

It was not possible to compare results between studies directly due to variation in the methods used, and therefore a meta-analysis was not conducted.

\section{Results}

The process of identifying studies for inclusion is summarised in Figure 1. Searches identified 1,929 articles, with 1,279 remaining following deletion of 650 duplicates. 1,169 articles were excluded based on the title/abstract, leaving a pool of 110 articles for further screening. After examination of full text and the addition of articles cited within these and from other sources, 18 articles met the criteria for inclusion, none of which were based on 
data from the same study giving a total of 18 studies. Studies are summarised in Table 1 which lists studies from the oldest to the most recent in order to help elucidate temporal trends. Studies are reviewed narratively below in relation to three themes (one study contributes to two themes): laxative types; interventions (dietary fibre, abdominal massage and macrogol); and staff issues (knowledge and training). A further two studies on medication were identified but these were excluded as they are not included in current constipation management guidelines. One study looked at Cisapride (Staiano et al., 1996) but this has now been withdrawn from most of the world's health institutes because of its recorded fatalities in addition to serious side effects such as severe arrhythmias (Aboumarzouk et al., 2011). The second study looked at Colchicine (Frame et al., 1998) which has been associated with increased occurrence of abdominal pain, and long-term use may cause granulocytopenia, renal dysfunction, reversible myopathy or neuropathy and hepatitis (Jiang et al., 2015).

\section{Geography}

All studies were from high income countries: four from England, three from the Netherlands, two from Belgium, two from the United States, and one each from Australia, France, Hong Kong, Ireland, Italy, Scotland, and Wales.

\section{MMAT Quality Appraisal}

Information on MMAT types and scores is given in the first column of Table 1. Only one study met all MMAT criteria, four scored $3^{*}, 10 \operatorname{scored} 2^{*}$, three scored $1^{*}$, and one study did not meet any criteria due to a lack of reported methodological detail. The most common unmet criteria are outlined below.

Qualitative: quality was limited by the lack of reported methodological detail in the two studies resulting in predominantly 'can't tell' ratings. 
Quantitative descriptive: only one of the nine studies met criterion two, 'Is the sample representative of the population under study?'.

Quantitative randomized controlled: only one of the four studies met criterion one, 'Is there a clear description of the randomization (or an appropriate sequence generation)?'.

Quantitative non-randomized: No study in this group had a control group making criterion three relating to comparability of groups not applicable. Only one of the four studies met criterion one 'Are participants (organizations) recruited in a way that minimizes selection bias?'.

\section{Laxative Types}

The type of laxatives used by participants is outlined in seven quantitative descriptive studies (Böhmer et al., 2001, Connor et al., 2014, Joos et al., 2016, van der Heide et al., 2009, Van Winckel et al., 1999, Veugelers et al., 2010, Ganesh et al., 1994). The highest quality study found that the most commonly used laxatives in children with severe generalized cerebral palsy mostly living in the family home were disaccharide $(24.3 \%$ of 152 children) and polyethylene glycol (macrogol) (13.2\% of 152 children) (Veugelers et al., 2010). The most recent study found that macrogol combinations were received by $48.1 \%$ of 156 institutionalised adults and children with profound intellectual disability using enteral feeding tubes in Belgium, the second most common medication received by this population after the anti-epileptic valproic acid (Joos et al., 2016). Macrogol combinations were also the most frequently prescribed laxative for adults and children with profound intellectual and multiple disabilities (PIMD) living in institutions in the Netherlands (30\% of 254 people with PIMD) followed by bisacodyl (29\%) and lactulose (14\%) (van der Heide et al., 2009). An earlier study in England found only four of 181 people living in community based care homes (2.2\%) to be taking macrogol, with the most frequent being lactulose (46 of $181 ; 25.4 \%)$ and senna (27 of $181 ; 14.9 \%)$ (Connor et al., 2014). 
A number of people with intellectual disability receive rectal laxatives, enemas or suppositories, with figures reported being $22.4 \%$ of 152 children with severe generalized cerebral palsy living mainly in the family home (Veugelers et al., 2010), 5.5\% of 181 residents living in a community based care homes in one trust area (Connor et al., 2014), 10\% of 215 adults and children with intellectual disability living in institutions (Böhmer et al., 2001), 57.9\% of 38 adults with profound intellectual disability in one institution (Ganesh et al., 1994), at least $10 \%$ of 254 adults and children with PIMD in institutions (10\% received sodium phosphate enemas, $3 \%$ docusate sodium but it is not possible to tell if these figures are mutually exclusive) (van der Heide et al., 2009), and 12.4\% of 420 adults and children with intellectual disability living in institutions (Van Winckel et al., 1999). One study found that in one institution, despite adult men and women having similar disabilities, most of those receiving suppositories were women and it is suggested that this may reflect different practice on the wards (Ganesh et al., 1994). Manual evacuation was also reported for $6.7 \%$ of 215 adults and children living in institutions (Böhmer et al., 2001) and 9.2\% of 152 children with severe generalized cerebral palsy mostly living in the family home (Veugelers et al., 2010).

Where reported, use of multiple laxatives was common. Of 149 adults and children with constipation living in institutions, $34.2 \%$ used two laxatives and $9.4 \%$ used three laxatives (figures include sodium phosphate enemas) (Böhmer et al., 2001). Of 65 community based care home residents taking laxatives in one trust area, 30.8\% used two laxatives, $15.4 \%$ used three laxatives, and $4.6 \%$ used more than three (figures include enemas/suppositories) (Connor et al., 2014).

Laxatives were not necessarily effective, with efficacy being variable in adults and children in institutions (Böhmer et al., 2001). In a randomized crossover studying comparing laxatives to abdominal massage for adults in an institution or associated group homes, $43 \%$ of participants showed no improvement in colonic transit time when on their usual laxative 
regime compared to the baseline period with no treatment (Emly et al., 1998). One study found that $36 \%$ of 83 children mainly living in the family home with severe generalized cerebral palsy taking laxatives nonetheless showed symptoms of constipation (Veugelers et al., 2010). In this latter study, of the total sample of 152 children, water intake was below recommended amounts for $86.5 \%$ of children and daily intake of fibre was below recommended amounts in 53.2\%, with six tube fed children receiving no fibre at all.

\section{Interventions}

Ten studies considered specific interventions for constipation. Five of these evaluated dietary interventions (fibre), three of which were quantitative randomized controlled trials and two of which were non-randomized studies. Four focused on abdominal massage: one was a quantitative randomized controlled trial; one was a non-randomized study; and two were qualitative studies obtaining feedback from those involved in implementing abdominal massage. One non-randomized study looked at the efficacy of polyethylene glycol 3350 plus electrolytes (PEG+E).

\section{Dietary Interventions}

All dietary interventions reported in this review considered the effect of dietary fibre. The dietary intervention study with the highest MMAT score looked at the effect of the dietary fibre glucomannan on chronic constipation in neurologically impaired children (Staiano et al., 2000). After 12 weeks of treatment with glucomannan, no side effects were reported and there were significant increases in stool frequency, significant reductions in laxative or suppository use, significant improvements in stool consistency, and significant reductions in episodes of painful defecation. With placebo, none of these improvements were found. However, neither glucomannan nor placebo had a measurable effect on total and segmental transit times. 
One study investigated the effect of adding fibre (All-Bran $\left.{ }^{\circledR}\right)$ to the breakfast of orally fed children living in a large institution (Tse et al., 2000). Baseline fibre intake was found to be very low at around $2 \mathrm{~g} /$ day. Increasing fibre intake to $17 \mathrm{~g} /$ day (stage 1) led to a significant reduction in laxative use. Increasing fibre intake further to $21 \mathrm{~g} /$ day (stage 2) led to a further reduction in the use of laxatives but there was no statistical significance between stage 1 and stage 2 of fibre supplementation.

A further study found that fibre and fluid intake were below recommended amounts in adult training centre residents with bowel dysfunction, and controlled trials of a dietary supplement with approximately $7 \mathrm{~g}$ additional fibre per day were subsequently undertaken (Capra and Hannan-Jones, 1992). In the treatment group, enemas reduced from seven to five per fortnight and the overall texture of bowel movements improved. Controls had no reduction in enemas (eight per fortnight), and experienced a significant reduction in the number of bowel motions and a worsening of stool texture. It should be noted that the dietary supplement also included the natural laxative dihydroxyphenyl isatin (found in prunes) which stimulates intestinal motility.

One crossover study looked at tolerance of a paediatric adapted enteral formula with added soy fibre in children (mostly in foster care) receiving enteral feeding and using elimination aids (Tolia et al., 1997). The formula with added fibre was well tolerated and there was a slight trend towards decreased use of elimination aids to induce a bowel movement during the fibre supplemented formula phase (i.e. more with spontaneous defecation).

One study looked at the effects of three levels (fibre free, 12 to $20 \mathrm{~g} / \mathrm{day}, 18$ to 25 $\mathrm{g}$ /day) of purified dietary fibre (soy polysaccharide) over a one year period on stool frequency, size and consistency in non-ambulatory, enterally fed youths with chronic constipation in an institution (after the study commenced five of the 11 participants were 
found to experience loose stools as a consequence of chronic antacid medication) (Liebl et al., 1990). Whilst the use of elimination aids was not reduced by either level of fibre, fibre was found to improve bowel function, with increases in daily stool frequency, stool moisture, wet stool weight and dry stool weight.

\section{Abdominal Massage}

In relation to abdominal massage, the study with the highest MMAT score used a randomised cross-over design to compare abdominal massage (five times a week for 20 mins) for adults in an institution or associated group homes with the participant's usual laxative regime (Emly et al., 1998). The effects of laxative and massage therapy for this group (48\% of whom always required an enema to defecate) were not demonstrably different. However, abdominal massage had no side effects and structured interviews with keyworkers provided anecdotal evidence of increased tolerance to touch and improved behaviour and communication, while the period of one-to-one contact was believed to enhance the therapist/nurse-patient relationship.

In a service development initiative in one area of England, parents of children with physical and learning disabilities or complex needs living in the family home were trained and asked to complete abdominal massage for 20 minutes a day over a 6 week period and record outcomes (Bromley, 2014). Results reported a wide range of quality of life improvements, including relief in symptoms of constipation (87.5\%), increase in optimal stool type from $13 \%$ to $59 \%$, reduction in laxative medication $(58 \%)$, improved dietary intake (41\%), and improved sleep pattern (37\%). Qualitative data indicated positive experiences described by parents which included enhanced parent-child relationships. The estimated annual cost saving from reduced laxative use was $£ 1,322.03$ whilst the estimated cost of education/training was $£ 35.20$ per family. However, parents were provided with information 
to increase their understanding of constipation and it is not clear to what extent positive results can be attributed solely to abdominal massage, for example some parents reported the introduction of toileting plans during the 6 week period.

In an area of England where abdominal massage was implemented as part of a total bowel management programme, a questionnaire consisting of open ended questions was sent to families and carers to gain feedback on the experiences of adults and children with intellectual disability living in the community and their carers with regards to abdominal massage (Connor et al., 2014). All feedback was positive and included ease of learning and implementation; bowel movement changes; improvements in pain, mood or behaviour; reduction of laxatives; and providing opportunities to develop the therapeutic relationship. However, as abdominal massage was part of a total bowel management programme which included attention to diet, fluid intake, mobility, and toilet regimen and positioning, it is again not clear to what extent positive results can be attributed solely to abdominal massage.

Finally, an audit 18 months after the introduction of abdominal massage in one area of England used a questionnaire with open ended questions to look at the views of nurses and healthcare workers involved in its implementation in a community based home for adults with profound physical disability and intellectual disability (Emly et al., 2001). There was a change in clinical practice and staff attitudes to bowel management, and increased confidence and knowledge of bowel care including more awareness of faecal impaction risk. There was greater emphasis on diet, fluid intake, exercise and passive movement. Initial anxieties regarding the withdrawal of laxatives were unfounded.

\section{Medication}

As noted previously, two studies relating to medication were excluded (Staiano et al., 1996, Frame et al., 1998) as the medications are not currently recommended. One study based on retrospective analysis of hospital and pharmacy records examined the safety and 
efficacy of polyethylene glycol 3350 plus electrolytes $(\mathrm{PEG}+\mathrm{E})$ for people with intellectual disability living in an institution who were treated with PEG+E for 24 months (MigeonDuballet et al., 2006). There were significant increases in the mean number of stools per patient per month and episodes of diarrhoea (which was defined as 'a large number of stools not necessarily watery'). PEG+E was not associated with adverse effects on body weight or blood biochemistry values. The total cost of laxatives per medical ward per year decreased from 3788.17 to 1767.39 Euros. However, whilst PEG+E was received by 54 participants, comparative data prior to the introduction of PEG+E was based on only 16 participants.

\section{Staff Related Issues}

Two quantitative descriptive studies provide information on staff related issues. One study using information from records and interviews with staff explored diet and bowel management (not restricted to constipation per se, e.g. includes encopresis) in adults with intellectual disability who had moved from a hospital to community based staffed homes four years previously (Dickson et al., 2002). An increase in bowel medication since moving to the community was associated with support by staff with no training, whilst a decrease was associated with support by staff with training. Eighteen staff $(41 \%)$ had any training in relation to diet and/or bowel management, 16 of whom had received a half-day course on basic nutrition from a dietician. None of the 44 participants received input from clinical psychology for behavioural management in relation to bowel control. For 41 of the 44 participants, support staff decided on their diet.

A survey of registered nurses supporting people with intellectual disability in one major intellectual disability service provider in Ireland found good overall knowledge regarding the prevention and management of constipation (Marsh and Sweeney, 2008). However, there were some knowledge deficits, for example $33 \%$ incorrectly identified the best position for having a bowel movement as on the toilet with feet hanging freely above the 
floor. In addition: only 64 (65\%) correctly identified anticonvulsants as increasing constipation; 68 (69\%) did not recognise diabetes as being associated with constipation; and whilst $81(83 \%)$ recognised the need for 5 daily portions of fruit or vegetables, $65(66 \%)$ correctly identified 2 litres of fluid a day as a minimum recommendation.

\section{Discussion}

Despite broad inclusion criteria, only 18 studies have been identified in relation to the management of constipation in people with intellectual disability. 'Interventions' was the theme covered in the greatest number of studies, and these were restricted to five intervention studies involving dietary fibre, two intervention studies involving abdominal massage, two studies obtaining staff/carer feedback on abdominal massage, and one retrospective study of PEG+E. 'Laxatives types' was also a common theme. Only two studies considered service related issues such as staff knowledge and training.

A number of studies including both institutional and family home based settings report below recommended levels of fluid and/or fibre intake in people with intellectual disability (Capra and Hannan-Jones, 1992, Tse et al., 2000, Veugelers et al., 2010), with the implication that improving intake may help with constipation. Indeed, all four studies looking at the effect of dietary fibre interventions report some positive results relating to bowel function and/or laxative/enema use. As suggested by Capra and Hannan-Jones (1992), even when there is chronic constipation, dietary intervention may be warranted. However, as noted by Tse et al (2000), increasing dietary fibre intake will not solve the problem of constipation entirely since there are many other related factors, e.g. medication, physical inactivity, possible underlying defects in gut innervation and musculature (related to spasticity) and inadequate fluid intake due to oromotor dysfunction. Indeed, in one study children continued to be chronically constipated, having a prolonged intestinal transit time 
despite improvements in outcomes such as stool frequency and painful defecation (Staiano et al., 2000).

Whilst the effectiveness of abdominal massage was found not to be demonstrably different to that of laxatives for adults in one study (Emly et al., 1998), a number of positive outcomes have been attributed to abdominal massage, both in relation to relief in the symptoms of constipation and secondary outcomes such as improved sleep in children (Bromley, 2014), improvements in pain, mood or behaviour (Connor et al., 2014), and enhanced therapeutic relationships between those implementing and receiving the abdominal massage across a range of settings (Emly et al., 1998, Bromley, 2014, Connor et al., 2014). Concomitant reduction in laxative use for children living in the family home was also associated with cost savings (Bromley, 2014). However, it is not clear to what extent positive results can be attributed solely to abdominal massage, with implementation being confounded by, for example, the introduction of toileting plans during the study period (Bromley, 2014) or by additional components of a total bowel management programme (Connor et al., 2014).

A wide range of laxative types were reported to be used by people with intellectual disability (Böhmer et al., 2001, Connor et al., 2014, Joos et al., 2016, van der Heide et al., 2009, Van Winckel et al., 1999, Veugelers et al., 2010), most frequently osmotic variants. Laxative polypharmacy was common (Böhmer et al., 2001, Connor et al., 2014). A number of people with intellectual disability also received rectal laxatives, enemas or suppositories, with figures reported ranging from $5.5 \%$ of residents in community based care homes (Connor et al., 2014) to $57.9 \%$ of adults with profound intellectual disability in one institution (Ganesh et al., 1994). Manual evacuation was also reported for a small proportion of people with intellectual disability (Böhmer et al., 2001, Veugelers et al., 2010). Laxatives were not effective for all people with intellectual disability (Böhmer et al., 2001, Emly et al., 1998, Veugelers et al., 2010). However, only two studies provides information on laxative use for 
those living in community based settings (Connor et al., 2014, Veugelers et al., 2010) and older institutional based studies may report practices that are no longer common.

The one study specifically on laxative effectiveness identified suggests that PEG+E is safe and effective in the clinical management of constipation in people with intellectual disability in an institutional setting (Migeon-Duballet et al., 2006). In relation to the general population, PEG received a 'grade A' recommendation for improving stool frequency and consistency (Zurad and Johanson, 2011). Two recent studies involving institutional settings found that macrogol (polyethylene glycol) combinations were the most commonly prescribed laxative for people with profound intellectual disability (Joos et al., 2016, van der Heide et al., 2009). However, care should be taken when using PEG in people who have dysphagia where liquids are thickened with starch, as a precipitous loss of thickening has been found to occur to liquids when PEG is added, although PEG may be compatible with xanthan gum based thickeners (Carlisle et al., 2016).

Support staff have the potential to play a vital role in the management of constipation in people with intellectual disability, for example they are often in control of the diet people with intellectual disability receive (Dickson et al., 2002). However, only two studies provide any information in relation to this theme. For registered nurses supporting people with intellectual disability in Ireland, some deficits have been found in knowledge regarding the prevention and management of constipation (Marsh and Sweeney, 2008) and it is plausible that knowledge deficits could be greater in non-nursing support staff. Staff training in relation to diet and/or bowel management has been found to be associated with a decrease in bowel medication for adults following a move to the community from a hospital setting, with increases being associated with support by staff with no training (Dickson et al., 2002). Dickson et al note that training may play a role in two ways: making staff alert to the 
requirements of a healthy diet in relation to bowel management; and making staff alert to the need to refer clients to GPs for monitoring and adjustment of medication.

Given how common constipation is in people with intellectual disability and the impact it can have on health and quality of life, the lack of research on the management of constipation is surprising. There is a particular lack of research in relation to managing constipation in community based settings. The lack of research and lack of comparison of interventions against each other mirrors the findings of a systematic review of management for those with central neurological disease (Coggrave et al., 2014). Many topics remain to be the subject of research for people with intellectual disability and constipation including: the role of toileting and the toileting environment; the impact of educating staff, carers and people with intellectual disability about constipation; the impact of diet, exercise, fluid intake, or other service related initiatives to try to reduce constipation; and whether learning disability nurses could take a role in education regarding constipation. In addition, no research has been done with people with intellectual disability in relation to approaches to managing constipation including probiotics (Dimidi et al., 2014); transcutaneous electrical stimulation (TES) (Hutson et al., 2015); and physiotherapeutic methods of connective tissue manipulation and Kinesio Taping (Orhan et al., 2016).

Behavioural approaches also warrant further research. It has been suggested that classical and operant treatment methods appear to be the best supported interventions for encopresis, soiling and constipation in children and adults with developmental disability (Matson and Lovullo, 2009). One study (which did not meet the inclusion criteria for this review) used a behavioural approach involving prompted toilet-sitting after meals, rewards for appropriate evacuation and increased fibre in four people with intellectual disability who suffered from chronic constipation, faecal impaction, soiling and were long term users of elimination aids (Smith et al., 1994). Training resulted in near normal bowel function, 
although training time was long and it was unclear which elements of the programme were essential to success. The authors note that the work is costly due to the intensive and prolonged nature of the programme and the field is vastly under resourced. One study in this review found that no people with intellectual disability received clinical psychology input for behavioural management in relation to bowel control (Dickson et al., 2002).

Numerous clinical guidelines for managing constipation exist, with one international study identifying 22 clinical practice guidelines for constipation (Tian et al., 2016). Some specifically exclude those with developmental delay (Tabbers et al., 2014). In England and Wales, NICE clinical guidelines for managing constipation in children exist (NICE, 2010) and these specifically state that assessment and management for those with physical disabilities (such as cerebral palsy), Down syndrome or autism should happen in the same way as is recommended for all children and young people (NICE, 2010, p 4-5). Clinical knowledge regarding constipation in adults has also been summarised by NICE (NICE, 2015). However, no clinical guidelines appear to be available specifically for people with intellectual disability.

It has been suggested that national clinical guidelines on constipation in adults with intellectual disability could be formulated so that healthcare workers would have an evidence-based framework to consult (Cockburn-Wells, 2014). In one area of England, failure of current practice to effectively manage constipation led a multi-professional group of health care practitioners to review evidence and develop a clinical guideline for the management of chronic constipation of adults within the community including people with intellectual disability (Emly and Rochester, 2006) and this guideline has recently been updated (Emly and Marriott, 2017). The guideline recommends a multi-faceted treatment strategy involving several health care professionals in the holistic management process, with an individualized programme rather than relying solely on prescription of laxatives. Early 
indications on use of the guideline with people with intellectual disability suggest that holistic, individualised bowel management programmes can reduce laxative use and nursing interventions and lead to improved quality of life (Emly and Rochester, 2006).

Raising awareness of the issue of constipation in people with intellectual disability may lead to further efforts within services to address the management of constipation. For example, following an event on constipation by the Public Health England Learning Disabilities Observatory, a group was formed in Central Midlands which aims to improve awareness and treatment of constipation in people with intellectual disability (Whait, 2016).

Böhmer et al (2001) note that until research provides clear answers as to how to manage constipation in people with intellectual disability, the principles for treatment are the same for individuals with intellectual disability as for the general population. As a basic principle, it has been suggested that bowel management should begin with the "eight keys to bowel success" prior to developing an individualised bowel programme: physical exercise, high fibre intake, high fluid intake, consistent habit time, an upright position on toilet or commode, privacy, medication management, and patient and family education (Weeks, Hubbartt, \& Michaels, 2000). Whilst early studies on constipation management for people with intellectual disability focused on specific elements of constipation management (e.g. dietary fibre), a recent study considers the management of constipation using abdominal massage in the context of a total bowel management programme (Connor et al., 2014). As noted by Emly et al (1998), maximum benefit of both laxative and abdominal massage interventions will be obtained only within a more general individualised programme of bowel management that addresses additional factors such as diet, exercise and toileting. Further research is required to support early indications that an integrated bowel management programme may be appropriate for managing constipation in people with intellectual disability (Emly and Rochester, 2006). 


\section{Limitations}

A limitation of this review is the potential loss of information from two main sources. First, the review has not considered how studies regarding approaches to managing constipation in other populations may be applicable to people with intellectual disability. For example, a study involving children and adults with quadriplegic cerebral palsy looked at a nursing intervention using non-pharmacological conservative therapy (intestinal massage; abdominal press; increase in water intake; increase in the use of vegetable oils in main meals; increase in the consumption of laxative fruits, leafy vegetables, and high fibre foods; and decrease in the consumption of constipating foods) (Faleiros and de Paula, 2013). Complete or partial improvement of constipation was observed in $90 \%$ of the patients, laxative use was reduced and there were improvements in sleep patterns, appetite, and mood (Faleiros and de Paula, 2013). Second, the review does not consider research relating to specific syndromes associated with intellectual disability such Rett syndrome. In addition, whilst studies were identified from a range of countries, the review is restricted to English language publications. No studies were identified from low and middle income (LAMI) countries. Finally, all data was extracted by one reviewer and checked for accuracy and completeness by a second reviewer. Whilst this is an accepted minimum (Centre for Reviews and Dissemination, 2009), extraction of data by two reviewers independently would have reduced the possibility of errors.

\section{Conclusion}

It is clear that the main management response to constipation in people with intellectual disability is laxative use but this is not effective for all people with intellectual disability. Awareness of the issue of constipation management in people with intellectual disability needs to be raised. An improved evidence base with robust high quality studies is required to better understand what works well in managing constipation in people with intellectual 
disability. This should include research to test the suggestion that the best way to manage constipation for people with intellectual disability is an individualised, integrated bowel management programme. In the meantime, services should consider adopting the guidelines for the management of chronic constipation of adults within the community (Emly and Marriott, 2017) which are available online at https://www.ndti.org.uk/uploads/files/ConstipationGuideline2016.pdf. In addition, a recent report provides information on reasonable adjustments that can be made for managing constipation in people with intellectual disability (Marriott and Emly, 2016). The ideas, information and examples of good practice in relation to managing constipation provided within these resources should help services improve provision for this highly prevalent condition and potentially reduce ill health and deaths associated with constipation in people with intellectual disability. 


\section{Appendix One}

\section{Example of Database Specific Search Terms (Medline)}

Limiters: Jan 1990 - 2017; English language.

( ( (MH "Constipation") OR (MH "laxatives") OR (MH "fecal impaction") OR ( TI constipat* OR TI fecal OR TI faecal OR TI laxative* OR TI defecat* OR TI defaecat* OR TI bowel OR TI colon* OR AB constipat* OR AB fecal OR AB faecal OR AB laxative* OR AB defecat* OR AB defaecat* OR AB bowel OR AB colon*)) ) AND ( ( (TI ( learning N1 (disab* or difficult* or handicap*) ) OR TI ( mental* N1 (retard* or disab* or deficien* or handicap* or disorder*) ) OR TI ( intellectual* N1 (disab* or impair* or handicap*) ) OR TI development* N1 disab* OR TI ( multipl* N1 (handicap* or disab*) ) OR TI "Down* syndrome" OR (MH "Developmental Disabilities") OR (MH "Intellectual Disability") OR (MH "mentally disabled persons")) OR (AB ( learning N1 (disab* or difficult* or handicap*) ) OR AB ( mental* N1 (retard* or disab* or deficien* or handicap* or disorder*) ) OR AB ( intellectual* N1 (disab* or impair* or handicap*) ) OR AB development* N1 disab* OR AB ( multipl* N1 (handicap* or disab*) ) OR AB"Down* syndrome") ) ) 


\section{References}

Aboumarzouk O. M., Agarwal T., Antakia R., Shariff U. \& Nelson R. L. (2011) Cisapride for intestinal constipation. Cochrane Database of Systematic Reviews, Issue 1, Art. No. CD007780.

Addison R., Davies C., Haslam D., Powell M. \& Stowers L. (2003) A national audit of chronic constipation in the community. Nursing Times, 99, 34-35.

Baikie G., Ravikumara M., Downs J., Naseem N., Wong K., Percy A., Lane J., Weiss B., Ellaway C., Bathgate K. \& Leonard H. (2014) Gastrointestinal dysmotility in Rett syndrome. Journal Of Pediatric Gastroenterology And Nutrition, 58, 237-244.

Balogh R., Brownell M., Ouellette-Kuntz H. \& Colantonio A. (2010) Hospitalisation rates for ambulatory care sensitive conditions for persons with and without an intellectual disability - a population perspective. Journal of Intellectual Disability Research, 54, 820-832.

Balogh R. S., Ouellette-Kuntz H., Brownell M. \& Colantonio A. (2011) Ambulatory Care Sensitive Conditions in Persons with an Intellectual Disability - Development of a Consensus. Journal of Applied Research in Intellectual Disabilities, 24, 150-158.

Bandla H. P., Davis S. H. \& Hopkins N. E. (1999) Lipoid pneumonia: a silent complication of mineral oil aspiration. Pediatrics, 103, E19-E19.

Belsey J., Greenfield S., Candy D. \& Geraint M. (2010) Systematic review: impact of constipation on quality of life in adults and children. Alimentary Pharmacology \& Therapeutics, 31, 938-949.

Bharucha A. E., Pemberton J. H. \& Locke G. R. (2013) American Gastroenterological Association Technical Review on Constipation. Gastroenterology, 144, 218-238. 
Böhmer C. J. M., Taminiau J. A. J., Klinkenberg-Knol E. C. \& Meuwissen S. G. M. (2001) The prevalence of constipation in institutionalized people with intellectual disability. Journal of Intellectual Disability Research, 45, 212-218.

Bosch J., Van Dyke D. C., Smith S. M. \& Poulton S. (1997) Role of Medical Conditions in the Exacerbation of Self-Injurious Behavior: An Exploratory Study. Mental Retardation, 35, 124-130.

Braun V. \& Clarke V. (2006) Using thematic analysis in psychology. Qualitative Research in Psychology, 3, 77-101.

Bromley D. (2014) Abdominal massage in the management of chronic constipation for children with disability. Community Practitioner, 87, 25-29.

Capra S. M. \& Hannan-Jones M. (1992) A controlled dietary trial for improving bowel function in a group of training centre residents with severe or profound intellectual disability. Australia \& New Zealand Journal of Developmental Disabilities, 18, 111121.

Carlisle B. J., Craft G., Harmon J. P., Ilkevitch A., Nicoghosian J., Sheyner I. \& Stewart J. T. (2016) PEG and Thickeners: A Critical Interaction Between Polyethylene Glycol Laxative and Starch-Based Thickeners. Journal of the American Medical Directors Association, 17, 860-861.

Carr E. G. \& Smith C. E. (1995) Biological setting events for self-injury. Mental Retardation and Developmental Disabilities Research Reviews, 1, 94-98.

Christensen T. J., Ringdahl J. E., Bosch J. J., Falcomata T. S., Luke J. R. \& Andelman M. S. (2009) Constipation Associated with Self-Injurious and Aggressive Behavior Exhibited by a Child Diagnosed with Autism. Education \& Treatment of Children, 32, 89-103. 
Citronberg J., Kantor E. D., Potter J. D. \& White E. (2014) A Prospective Study of the Effect of Bowel Movement Frequency, Constipation, and Laxative Use on Colorectal Cancer Risk. American Journal of Gastroenterology, 109, 1640-1649.

Cleaver S., Hunter D. \& Ouellette-Kuntz H. (2009) Physical mobility limitations in adults with intellectual disabilities: a systematic review. Journal of Intellectual Disability Research, 53, 93-105.

Cockburn-Wells H. (2014) Managing constipation in adults with severe learning disabilities. Learning Disability Practice, 17, 16-22.

Coggrave M., Norton C. \& Cody J. D. (2014) Management of faecal incontinence and constipation in adults with central neurological diseases. Cochrane Database of Systematic Reviews, Issue 1, Article No. CD002115.

Coleman J. \& Spurling G. (2010) Constipation in people with learning disability. BMJ, 340:c222.

Connor M., Hunt C., Lindley A. \& Adams J. (2014) Using abdominal massage in bowel management. Nursing Standard, 28, 37-42.

De Hert M., Hudyana H., Dockx L., Bernagie C., Sweers K., Tack J., Leucht S. \& Peuskens J. (2011) Second-generation antipsychotics and constipation: A review of the literature. European Psychiatry, 26, 34-44.

Dickson K., Paxton D. \& McKenzie K. (2002) Moving on. Learning Disability Practice, 5, $11-13$.

Dimidi E., Christodoulides S., Fragkos K. C., Scott S. M. \& Whelan K. (2014) The effect of probiotics on functional constipation in adults: a systematic review and meta-analysis of randomized controlled trials. American Journal of Clinical Nutrition, 100, 10751084. 
Emerson E. (2005) Underweight, obesity and physical activity in adults with intellectual disability in supported accommodation in Northern England. Journal of Intellectual Disability Research, 49, 134-143.

Emly M., Cooper S. \& Vail A. (1998) Colonic motility in profoundly disabled people: A comparison of massage and laxative therapy in the management of constipation. Physiotherapy, 84, 178-183.

Emly M. \& Marriott A. (2017) Revisiting constipation management in the community. British Journal of Community Nursing, 22, 168-172.

Emly M. \& Rochester P. (2006) A new look at constipation management in the community. British Journal of Community Nursing, 11, 326-332.

Emly M., Wilson L. \& Darby J. (2001) Abdominal massage for adults with learning disabilities. Nursing Times, 97, 61-62.

Every-Palmer S., Newton-Howes G. \& Clarke M. J. (2017) Pharmacological treatment for antipsychotic-related constipation. Cochrane Database of Systematic Reviews, Issue 1, Article No. CD011128.

Faleiros F. \& de Paula E. D. R. (2013) Constipation in patients with quadriplegic cerebral palsy: intestinal reeducation using massage and a laxative diet. Revista Da Escola De Enfermagem Da Usp, 47, 835-841.

Flynn M. \& Eley R. (2015a) Factors leading to James' and Amy’s compromised health status. Suffolk Safeguarding Adults Board, Suffolk County Council. Available online at http://www.suffolkas.org/safeguarding-adults-reviews/ (accessed 3 Nov 2015).

Flynn M. \& Eley R. (2015b) A Serious Case Review: Amy. Suffolk Safeguarding Adults Board, Suffolk County Council. Available online at http://www.suffolkas.org/safeguarding-adults-reviews/ (accessed 3 Nov 2015). 
Flynn M. \& Eley R. (2015c) A Serious Case Review: James. Suffolk Safeguarding Adults Board, Suffolk County Council. Available online at http://www.suffolkas.org/safeguarding-adults-reviews/ (accessed 3 Nov 2015).

Frame P. S., Dolan P., Kohli R. \& Eberly S. W. (1998) Use of colchicine to treat severe constipation in developmentally disabled patients. Journal of the American Board Of Family Practice, 11, 341-346.

Friedmacher F. \& Puri P. (2013) Hirschsprung's disease associated with Down syndrome: a meta-analysis of incidence, functional outcomes and mortality. Pediatric Surgery International, 29, 937-946.

Ganesh S., Potter J. \& Fraser W. (1994) An audit of physical health needs of adults with profound learning disability in a hospital population. Mental Handicap Research, 7, 228-236.

Giesbers S., Didden R., Radstaake M., Korzilius H., von Gontard A., Lang R., Smeets E. \& Curfs L. M. G. (2012) Incontinence in Individuals with Rett Syndrome: A Comparative Study. Journal Of Developmental \& Physical Disabilities, 24, 287-300.

Glover G. \& Evison F. (2013) Hospital Admissions That Should Not Happen: Admissions for Ambulatory Care Sensitive Conditions for People with Learning Disabilities in England. Improving Health \& Lives: Learning Disabilities Observatory. Available online at http://webarchive.nationalarchives.gov.uk/20160704160905/http://www.improvinghe althandlives.org.uk/publications/1169/Hospital_admissions_that_should_not_happen (accessed 16 August 2017).

Glover G., Williams R., Branford D., Avery R., Chauhan U., Hoghton M. \& Bernard S. (2015) Prescribing of psychotropic drugs to people with learning disabilities and/or autism by general practitioners in England. Public Health England. Available online 
at

http://webarchive.nationalarchives.gov.uk/20160704160901/http://www.improvinghe althandlives.org.uk/publications/1248/Prescribing_of_psychotropic_medication_for_p eople_with_learning_disabilities_and_autism (accessed 16 August 2017).

Goday-Arno A., Cerda-Esteva M., Flores-Le-Roux J. A., Chillaron-Jordan J. J., Corretger J. M. \& Cano-Pérez J. F. (2009) Hyperthyroidism in a population with Down syndrome (DS). Clinical Endocrinology, 71, 110-114.

Hermans H. \& Evenhuis H. M. (2014) Multimorbidity in older adults with intellectual disabilities. Research In Developmental Disabilities, 35, 776-783.

Humphries K., Traci M. A. \& Seekins T. (2009) Nutrition and Adults With Intellectual or Developmental Disabilities: Systematic Literature Review Results. Intellectual And Developmental Disabilities, 47, 163-185.

Hutson J. M., Dughetti L., Stathopoulos L. \& Southwell B. R. (2015) Transabdominal electrical stimulation (TES) for the treatment of slow-transit constipation (STC). Pediatric Surgery International, 31, 445-451.

Jiang C., Xu Q., Wen X. \& Sun H. (2015) Current developments in pharmacological therapeutics for chronic constipation. Acta Pharmaceutica Sinica B, 5, 300-309.

Joos E., Mehuys E., Remon J. P., Van Winckel M. \& Boussery K. (2016) Analysis of drug use in institutionalized individuals with intellectual disability and tube feeding. Acta Clinica Belgica, 71, 76-80.

Kozma C. \& Mason S. (2003) Survey of nursing and medical profile prior to deinstitutionalization of a population with profound mental retardation. Clinical Nursing Research, 12, 8-27.

Leung L., Riutta T., Kotecha J. \& Rosser W. (2011) Chronic Constipation: An EvidenceBased Review. The Journal of the American Board of Family Medicine, 24, 436-451. 
Liebl B. H., Fischer M. H., Van Calcar S. C. \& Marlett J. A. (1990) Dietary fiber and longterm large bowel response in enterally nourished nonambulatory profoundly retarded youth. Journal Of Parenteral And Enteral Nutrition, 14, 371-375.

Longstreth G. F., Thompson W. G., Chey W. D., Houghton L. A., Mearin F. \& Spiller R. C. (2006) Functional Bowel Disorders. Gastroenterology, 130, 1480-1491.

Marriott A. \& Emly M. (2016) Making reasonable adjustments for people with learning disabilities in the management of constipation. Public Health England. Available online at https://www.ndti.org.uk/uploads/files/Constipation_RA_report_final.pdf (accessed 16 August 2017). .

Marsh L. \& Sweeney J. (2008) Nurses' knowledge of constipation in people with learning disabilities. British Journal of Nursing, 17, S11-16.

Matson J. \& Lovullo S. V. (2009) Encopresis, soiling and constipation in children and adults with developmental disability. Research in Developmental Disabilities, 30, 799-807.

Migeon-Duballet I., Chabin M., Gautier A., Mistouflet T., Bonnet M., Aubert J. M. \& Halphen M. (2006) Long-term efficacy and cost-effectiveness of polyethylene glycol 3350 plus electrolytes in chronic constipation: a retrospective study in a disabled population. Current Medical Research And Opinion, 22, 1227-1235.

Moher D., Liberati A., Tetzlaff J. \& Altman D. G. (2009) Preferred reporting items for systematic reviews and meta-analyses: the PRISMA statement. BMJ, 339: b2535

Mugie S. M., Benninga M. A. \& Di Lorenzo C. (2011) Epidemiology of constipation in children and adults: a systematic review. Best Practice \& Research Clinical Gastroenterology, 25, 3-18.

NICE (2010) Constipation in children and young people: diagnosis and management of idiopathic childhood constipation in primary and secondary care (CG99). National 
Institute of Health \& Clinical Excellence, available online at http://www.nice.org.uk/guidance/cg99 (accessed 10 Dec 2015).

NICE (2015) Clinical Knowledge Summary (CKS): Constipation. National Institute for Health and Care Excellence. Available online at:

http://cks.nice.org.uk/constipation\#!background (accessed 11 October 2016).

Orhan C., Kaya Kara O., Kaya S., Akbayrak T., Kerem Gunel M. \& Baltaci G. (2016) The effects of connective tissue manipulation and Kinesio Taping on chronic constipation in children with cerebral palsy: a randomized controlled trial. Disability and Rehabilitation, Online ahead of print, 1-11.

Pluye P., Robert E., Cargo M., Bartlett G., O'Cathain A., Griffiths F., Boardman F., Gagnon M.-P. \& Rousseau M. (2011) Proposal: A mixed methods appraisal tool for systematic mixed studies reviews. Retrieved from http://mixedmethodsappraisaltoolpublic.pbworks.com (21 March 2017). Archived by Webcite ${ }^{\circledR}$ at http://www.webcitation.org/5tTRTc9yJ.

Robertson J., Baines S., Emerson E. \& Hatton C. (2017) Prevalence of constipation in people with intellectual disability: a systematic review. Journal of Intellectual \& Developmental Disability, Online ahead of print.

Robertson J., Emerson E., Gregory N., Hatton C., Turner S., Kessissoglou S. \& Hallam A. (2000) Lifestyle related risk factors for poor health in residential settings for people with intellectual disabilities. Research In Developmental Disabilities, 21, 469-486.

Sbahi H. \& Cash B. D. (2015) Chronic Constipation: a Review of Current Literature. Current Gastroenterology Reports, 17, 47.

Schwartzman F., Vítolo M. R., Schwartzman J. S. \& Morais M. B. d. (2008) Eating practices, nutritional status and constipation in patients with Rett syndrome. Arquivos De Gastroenterologia, 45, 284-289. 
Serrano Falcón B., Barceló López M., Mateos Muñoz B., Álvarez Sánchez A. \& Rey E. (2016) Fecal impaction: a systematic review of its medical complications. BMC Geriatrics, 16, 4.

Sherman S. L., Allen E. G., Bean L. H. \& Freeman S. B. (2007) Epidemiology of Down syndrome. Mental Retardation And Developmental Disabilities Research Reviews, 13, 221-227.

Smith L. J., Franchetti B., McCoull K., Pattison D. \& Pickstock J. (1994) A behavioural approach to retraining bowel function after long-standing constipation and faecal impaction in people with learning disabilities. Developmental Medicine And Child Neurology, 36, 41-49.

Souto R. Q., Khanassov V., Hong Q. N., Bush P. L., Vedel I. \& Pluye P. (2015) Systematic mixed studies reviews: Updating results on the reliability and efficiency of the mixed methods appraisal tool. International Journal of Nursing Studies, 52, 500-501.

Staiano A., Giudice E., Simeone D., Miele E. \& Marino A. (1996) Cisapride in neurologically impaired children with chronic constipation. Digestive Diseases And Sciences, 41, 870-874.

Staiano A., Simeone D., Del Giudice E., Miele E., Tozzi A. \& Toraldo C. (2000) Effect of the dietary fiber glucomannan on chronic constipation in neurologically impaired children. The Journal Of Pediatrics, 136, 41-45.

Straetmans J. M., van Schrojenstein Lantman-de Valk H. M. J., Schellevis F. G. \& Dinant G.J. (2007) Health problems of people with intellectual disabilities: the impact for general practice. British Journal of General Practice, 57, 64-66.

Tabbers M. M., DiLorenzo C., Berger M. Y., Faure C., Langendam M. W., Nurko S., Staiano A., Vandenplas Y. \& Benninga M. A. (2014) Evaluation and treatment of functional constipation in infants and children: evidence-based recommendations from 
ESPGHAN and NASPGHAN. Journal Of Pediatric Gastroenterology And Nutrition, $58,258-274$.

Tian H., Ding C., Gong J., Ge X., McFarland L. V., Gu L., Chen Q., Ma C., Zhu W., Li J. \& Li N. (2016) An appraisal of clinical practice guidelines for constipation: a right attitude towards to guidelines. Bmc Gastroenterology, 16, 52.

Tolia V., Ventimiglia J. \& Kuhns L. (1997) Gastrointestinal tolerance of a pediatric fiber formula in developmentally disabled children. Journal Of The American College Of Nutrition, 16, 224-228.

Tse P. W., Leung S. S., Chan T., Sien A. \& Chan A. K. (2000) Dietary fibre intake and constipation in children with severe developmental disabilities. Journal of Paediatrics And Child Health, 36, 236-239.

van der Heide D. C., van der Putten A. A. J., van den Berg P. B., Taxis K. \& Vlaskamp C. (2009) The documentation of health problems in relation to prescribed medication in people with profound intellectual and multiple disabilities. Journal of Intellectual Disability Research, 53, 161-168.

van Timmeren E. A., van der Putten A. A. J., Lantman-de Valk H., van der Schans C. P. \& Waninge A. (2016) Prevalence of reported physical health problems in people with severe or profound intellectual and motor disabilities: a cross-sectional study of medical records and care plans. Journal of Intellectual Disability Research, 60, 11091118.

Van Winckel M., Vander Stichele R., De Bacquer D. \& Bogaert M. (1999) Use of laxatives in institutions for the mentally retarded. European Journal Of Clinical Pharmacology, 54, 965-969.

Veugelers R., Benninga M. A., Calis E. A., Willemsen S. P., Evenhuis H., Tibboel D. \& Penning C. (2010) Prevalence and clinical presentation of constipation in children 
with severe generalized cerebral palsy. Developmental Medicine \& Child Neurology, $52, \mathrm{e} 216-221$.

Watanabe T., Nakaya N., Kurashima K., Kuriyama S., Tsubono Y. \& Tsuji I. (2004) Constipation, laxative use and risk of colorectal cancer: The Miyagi Cohort Study. Eur J Cancer, 40, 2109-2115.

Whait L. (2016) Making reasonable adjustments for people with learning disabilities in the management of constipation. PMLD Link, 28, 29-30.

Zurad E. G. \& Johanson J. F. (2011) Over-the-counter laxative polyethylene glycol 3350: an evidence-based appraisal. Current Medical Research And Opinion, 27, 1439-1452. 
Figure 1

Flowchart of Study Identification

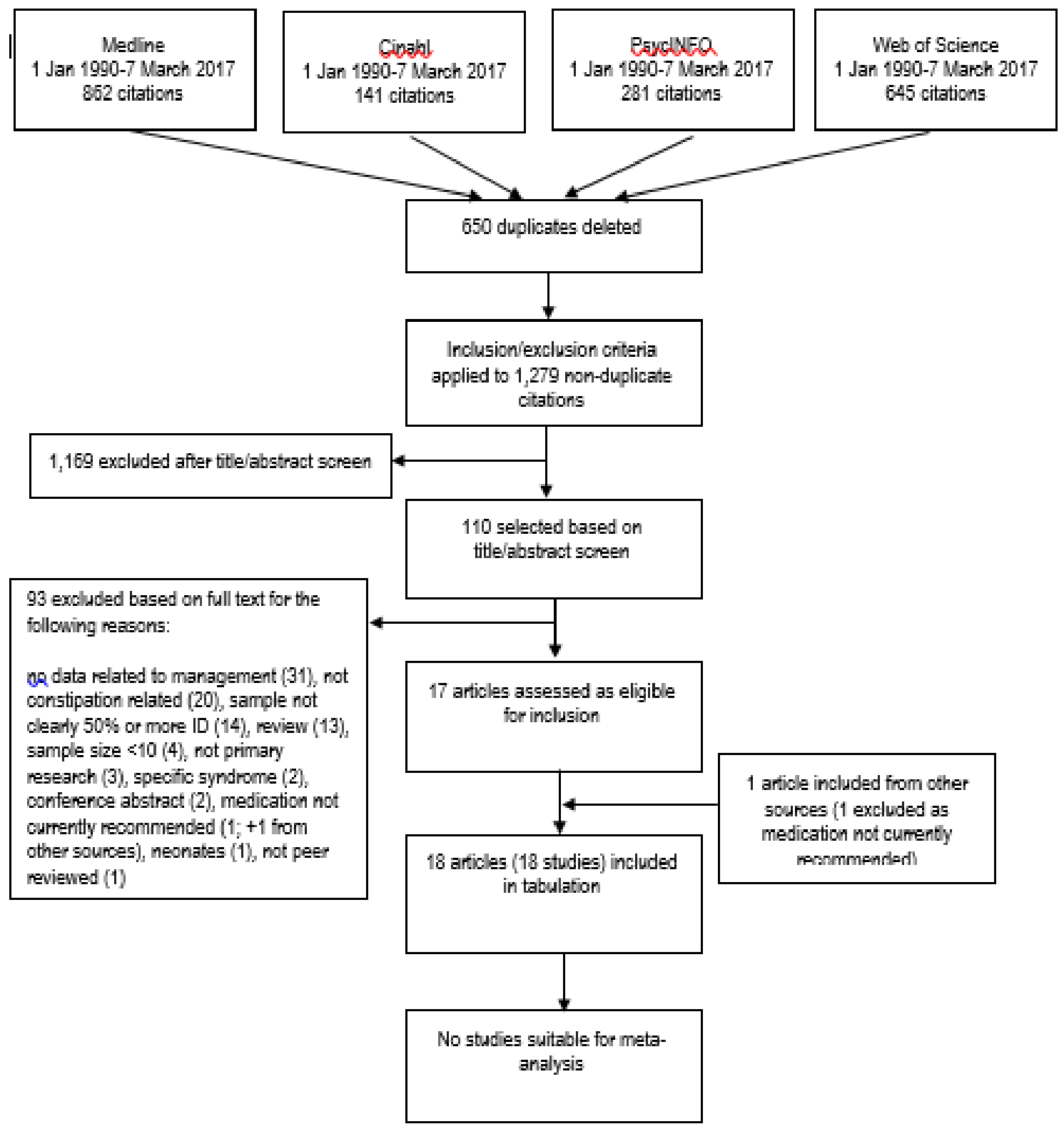


Table One: Summary of studies relating to the management of constipation in people with intellectual disability

\begin{tabular}{|c|c|c|c|c|c|c|c|c|c|c|}
\hline $\begin{array}{l}\text { MMAT } \\
\text { Type \& } \\
\text { Rating }\end{array}$ & $\begin{array}{l}\text { 1st Author } \\
\& \\
\text { Year }\end{array}$ & Country & $\begin{array}{l}\text { Management } \\
\text { Related Focus }\end{array}$ & Design & $\begin{array}{l}\text { Key sample features } \\
\text { (age group; setting) }\end{array}$ & $\begin{array}{r}\text { Sample } \\
\text { size }\end{array}$ & $\begin{array}{l}\text { Age range } \\
\text { (mean (SD); } \\
\text { median) }\end{array}$ & $\begin{array}{r}\% \\
\text { male }\end{array}$ & $\begin{array}{l}\text { Outcome } \\
\text { measures }\end{array}$ & Management Related Results \\
\hline$\underset{* *}{\text { QNR }}$ & $\begin{array}{l}\text { Liebl } \\
1990\end{array}$ & US & Dietary fibre & $\begin{array}{l}\text { Within subjects repeated } \\
\text { measures with } 3 \text { levels } \\
\text { of purified dietary fibre } \\
\text { source. i } 1-60 \text { days fibre } \\
\text { free liquid feeding, ii } \\
\text { days } 61-120 \& 121-300 \\
\text { added } 5 \mathrm{~g} / 240 \mathrm{ml} \text { purified } \\
\text { soy polysaccharide, iii } \\
\text { days } 301-360 \text { Soy } \\
\text { polysaccharide } \\
\text { concentration increased } \\
\text { by } 50 \% \text {. }\end{array}$ & $\begin{array}{l}\text { Non-ambulatory severely } \\
\text { developmentally } \\
\text { disabled youths resident } \\
\text { at a centre for the } \\
\text { developmentally } \\
\text { disabled, all enterally fed } \\
\& \text { chronically constipated } \\
\text { (child; institution) }\end{array}$ & 11 & $\begin{array}{l}7-17 \\
\text { (ns) }\end{array}$ & 46 & $\begin{array}{l}\text { Stool frequency; } \\
\text { size and } \\
\text { consistency; wet } \\
\text { and dry weight } \\
\text { from total stool } \\
\text { collections (last } \\
10 \text { days of each } \\
\text { period, and } 2 x \\
10 \text { days period } \\
\text { 4) }\end{array}$ & $\begin{array}{l}\text { Suppositories were given every } 3 \text { days if no BM. Use of elimination } \\
\text { aids not reduced by either level of fibre. The second fiber addition } \\
\text { significantly increased mean (SD) daily stool frequency from } 0.6 \text { (SD } \\
0.2 \text { ) during the fiber-free diet to } 1.1 \text { (SD 0.5). The first addition of fiber } \\
\text { compared to the fiber-free diet significantly increased stool moisture } \\
\text { from } 70 \% \text { (SD } 7 \% \text { ) to } 76 \% \text { (SD } 8 \% \text { ) and wet stool weight from } 30 \text { (SD } \\
\text { 13) g/day to } 53 \text { (SD } 21 \text { ); mean stool weight during days } 351 \text { to } 360 \\
\text { was } 87 \text { (SD } 45 \text { ) g/day. Daily dry stool weight significantly increased } \\
\text { with the second fiber addition. Soy polysaccharide fiber improved } \\
\text { bowel function in this nonambulatory profoundly disabled population }\end{array}$ \\
\hline$\underset{* *}{Q R C}$ & $\begin{array}{l}\text { Capra } \\
1992\end{array}$ & Australia & $\begin{array}{l}\text { Fibre \& fluid } \\
\text { intake; effect of } \\
\text { modifying dietary } \\
\text { fibre on bowel } \\
\text { function }\end{array}$ & $\begin{array}{l}3 \times \text { controlled trials: } 2 \\
\text { week baseline, } 2 \text { week } \\
\text { intervention, } 2 \text { week } \\
\text { post-intervention. } \\
\text { Intervention a dietary } \\
\text { supplement with approx } \\
7 \mathrm{~g} \text { additional fibre per } \\
\text { day as a mixture of } \\
\text { soluble and insoluble } \\
\text { fibres plus natural } \\
\text { laxative dihydroxyphenyl } \\
\text { isatin which stimulates } \\
\text { intestinal motility }\end{array}$ & $\begin{array}{l}\text { Adult training centre } \\
\text { residents with bowel } \\
\text { dysfunction; } 62.2 \% \\
\text { immobile; meals from } \\
\text { central kitchen } \\
\text { (adult; institution) }\end{array}$ & 37 & $19-72$ (ns) & 51 & $\begin{array}{l}\text { Number BM, } \\
\text { texture, number } \\
\text { of suppositories } \\
\text { or enemas used }\end{array}$ & $\begin{array}{l}\text { Estimates of fibre and fluid intakes yielded mean intakes of } 18.6 \mathrm{~g} \text { fibre } \\
\text { per day (range } 14-23 \mathrm{~g} \text { ) (current recommendations at the time were } \\
25-30 \mathrm{~g} \text { per day) and } 2.2 \text { litres of fluid (range } 1.8-2.4 \text { litres) - this } \\
\text { included approx } 1 \text { litre fluid in food (recommendation at the centre } \\
\text { was to give } 2-2.5 \text { litres fluid a day above that found in food). } \\
\text { Improving fibre and fluid intake may help with constipation } \\
\text { management and prevention. Controls had no reduction in enemas } \\
\text { ( } 8 \text { per fortnight), treatment group reduced from } 7 \text { to } 5 \text { per fortnight. } \\
\text { For treatment group overall texture of BM improved. Those not } \\
\text { receiving the supplement experienced a significant reduction in the } \\
\text { number of BMs and a worsening of stool texture, while those receiving } \\
\text { the supplement did not. Results suggest that, even when there is } \\
\text { chronic constipation, dietary intervention may be warranted }\end{array}$ \\
\hline$\underset{* *}{Q D}$ & $\begin{array}{l}\text { Ganesh } \\
1994\end{array}$ & Wales & Suppository use & Audit & $\begin{array}{l}\text { Adults with profound ID } \\
\text { living in one institution } \\
\text { (adult; institution) }\end{array}$ & 38 & $\begin{array}{l}24-54 \\
\text { (mean } 36.8 \\
\text { for males, } \\
33.7 \text { for } \\
\text { females) }\end{array}$ & 50 & $\begin{array}{l}\% \text { receiving } \\
\text { suppositories } \\
\text { regularly }\end{array}$ & $\begin{array}{l}\text { 22/38 ( } 57.9 \%) \text { were regularly taking suppositories for constipation. } 18 \\
\text { of the } 22 \text { were women despite men and women having similar } \\
\text { disabilities. Suggested that difference in use of suppositories } \\
\text { between men and women may be because they are on different } \\
\text { wards and reflect different practice on the wards. }\end{array}$ \\
\hline$\underset{* *}{Q R C}$ & $\begin{array}{l}\text { Tolia } \\
1997\end{array}$ & US & $\begin{array}{l}\text { Gastrointestinal } \\
\text { tolerance of a } \\
\text { pediatric enteral } \\
\text { formula } \\
\text { containing soy } \\
\text { fibre \& effect on } \\
\text { defecation }\end{array}$ & $\begin{array}{l}\text { Double blinded, } \\
\text { randomized, 2-month } \\
\text { crossover study. During } \\
\text { two phases of each 4- } \\
\text { week period of the } \\
\text { crossover study, } \\
\text { subjects were fed } \\
\text { Pediasure® either with } \\
\text { (PS10) or without (PS) }\end{array}$ & $\begin{array}{l}\text { Children receiving } \\
\text { enteral nutrition } \\
\text { supplements for }>80 \% \text { of } \\
\text { energy requirements. All } \\
\text { had difficulty with } \\
\text { defecation requiring } \\
\text { elimination aids for over } \\
6 \text { months duration. Most } \\
\text { in foster care }\end{array}$ & 20 & $\begin{array}{l}1-17 \\
(4.6(4.2) ; \\
3.3)\end{array}$ & 50 & $\begin{array}{l}\text { Gastrointestinal } \\
\text { tolerance } \\
\text { (incidence of } \\
\text { emesis and/or } \\
\text { spit up, gas, } \\
\text { irritability or } \\
\text { fussiness, } \\
\text { distention, } \\
\text { bloating), stool }\end{array}$ & $\begin{array}{l}\text { No differences in tolerance, stooling, growth, or biochemical } \\
\text { measurements between the feeding regimens, in } 11 \text { children } \\
\text { completing this phase of the study. Slight trend towards using less } \\
\text { elimination aids to induce a BM during fiber supplemented formula } \\
\text { phase (i.e. more with spontaneous defecation): } 2 \text { of } 11(18 \%) \\
\text { participants needed no elimination aids when using PS compared to } 3 \\
\text { of } 11(27 \%) \text { using PS10. Pediasure with fiber well tolerated in } \\
\text { children with developmental disabilities and possibly decreased use of } \\
\text { elimination aids. }\end{array}$ \\
\hline
\end{tabular}




\begin{tabular}{|c|c|c|c|c|c|c|c|c|c|c|}
\hline $\begin{array}{l}\text { MMAT } \\
\text { Type \& } \\
\text { Rating }\end{array}$ & $\begin{array}{l}\text { 1st Author } \\
\& \\
\text { Year }\end{array}$ & Country & $\begin{array}{l}\text { Management } \\
\text { Related Focus }\end{array}$ & Design & $\begin{array}{l}\text { Key sample features } \\
\text { (age group; setting) }\end{array}$ & $\begin{array}{r}\text { Sample } \\
\text { size }\end{array}$ & $\begin{array}{l}\text { Age range } \\
\text { (mean (SD); } \\
\text { median) }\end{array}$ & $\begin{array}{r}\% \\
\text { male }\end{array}$ & $\begin{array}{l}\text { Outcome } \\
\text { measures }\end{array}$ & Management Related Results \\
\hline & & & & $\begin{array}{l}10 \mathrm{~g} / \mathrm{l} \text { dietary soy fiber } \\
\text { (soy polysaccharide). } \\
\text { Following completion of } \\
\text { the crossover study, } \\
\text { subjects were fed } \\
\text { Pediasure } @ \text { with fiber for } \\
\text { an additional } 2 \text { months. }\end{array}$ & (child; most foster care) & & & & $\begin{array}{l}\text { characteristics, } \\
\text { elimination aid } \\
\text { use }\end{array}$ & \\
\hline 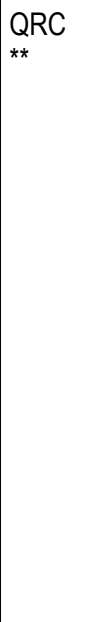 & $\begin{array}{l}\text { Emly } \\
1998\end{array}$ & England & $\begin{array}{l}\text { Comparison of } \\
\text { abdominal } \\
\text { massage \& } \\
\text { laxative therapy }\end{array}$ & $\begin{array}{l}\text { Randomised cross-over } \\
\text { design comparing } \\
\text { abdominal massage (x5 } \\
\text { a week for } 20 \text { mins) and } \\
\text { usual laxative regime. } \\
\text { Group i massage first, } \\
\text { group ii laxatives first. } 16 \\
\text { days baseline with no } \\
\text { treatment, and two } 7 \\
\text { week treatment phases } \\
\text { separated by one week } \\
\text { washout. Also } \\
\text { structured interviews } \\
\text { with key worker }\end{array}$ & $\begin{array}{l}\text { Adult residents of an } \\
\text { institution or } 2 \\
\text { associated group } \\
\text { homes; profound or } \\
\text { severe ID, with CP or } \\
\text { genetic conditions } \\
\text { associated with } \\
\text { abnormal muscle tone, } \\
\text { regular use of } \\
\text { laxative/enemas for } 12+ \\
\text { months before trial. } 90 \% \\
\text { on laxative/enemas } 5+ \\
\text { years; } 48 \% \text { always } \\
\text { required enema to } \\
\text { defecate } \\
\text { (adult; institution \& } 2 \\
\text { group homes) }\end{array}$ & 32 & $\begin{array}{l}\text { i. } 24-74 \\
(42.3 \text { (ns); } \\
\text { ns) } \\
\text { ii. } 27-61 \\
\text { ( } 43.5 \text { (ns); } \\
\text { ns) }\end{array}$ & 44 & $\begin{array}{l}\text { Gastro-intestinal } \\
\text { and segmental } \\
\text { transit times; } \\
\text { secondary } \\
\text { measures } \\
\text { included stool } \\
\text { frequency, size } \\
\text { and consistency, } \\
\text { the requirement } \\
\text { for enemas and } \\
\text { an assessment } \\
\text { of patient well- } \\
\text { being }\end{array}$ & $\begin{array}{l}\text { Median total colonic transit time was } 183 \text { hours for baseline phase } \\
\text { and } 159 \text { hours for all treatment phases. No evidence of any } \\
\text { statistically significant treatment differences between laxative and } \\
\text { massage therapy for right, left or rectosigmoid segments either } \\
\text { separately or in total. Analysis of secondary outcome measures also } \\
\text { failed to find any treatment preferences. The effects of laxative and } \\
\text { massage therapy within this environment were not demonstrably } \\
\text { different. } 43 \% \text { of subjects showed no improvement in colonic transit } \\
\text { time over baseline while on their previous laxative regimen adding } \\
\text { weight to clinical concern about long-term laxative dependency. } \\
\text { Results reveal grossly abnormal colonic transit times of the study } \\
\text { population at all times. Anecdotally, evidence from structured } \\
\text { interviews included reports of increased tolerance to touch and } \\
\text { improved behaviour and communication, while the period of one-to- } \\
\text { one contact was believed to enhance the therapist/nurse-patient } \\
\text { relationship. }\end{array}$ \\
\hline$\underset{* * \star}{\mathrm{QD}}$ & $\begin{array}{l}\text { Van } \\
\text { Winckel } \\
1999\end{array}$ & Belgium & $\begin{array}{l}\text { Laxative use as } \\
\text { an indirect } \\
\text { indicator of } \\
\text { constipation }\end{array}$ & $\begin{array}{l}\text { Cross-sectional } \\
\text { descriptive study using } \\
\text { structured interviews }\end{array}$ & $\begin{array}{l}\text { Patients with moderate } \\
\text { to profound ID living in } \\
\text { institutions } \\
\text { (adult } 73 \% \text {, child } 27 \% \text {; } \\
\text { institutions) }\end{array}$ & 420 & $\begin{array}{l}2-72 \\
\text { (ns (ns); 29) }\end{array}$ & 63 & Laxative use & $\begin{array}{l}\text { Enemas used chronically by } 12.4 \% \text { ( } 52 / 420) \text { of the residents, of whom } \\
23 \%(12 / 52) \text { needed an enema before each defecation. Seventy-nine } \\
\text { percent }(41 / 52) \text { used enemas in combination with oral laxatives. Fifty- } \\
\text { eight percent }(28 / 52) \text { used phosphate enemas }(0), 27 \%(14 / 52) \\
\text { sodium lauryl sulfate }(0) \text { or sodium docusate }(S), 13.5 \%(7 / 52) \\
\text { glycerine }(0) \text { and } 5.5 \%(3 / 52) \text { isotonic saline }(0) \text {. In } 70 \%(40 / 52) \text {, } \\
\text { enemas were given after a predetermined number of days without } \\
\text { defecation varying from } 2 \text { to } 12 \text { days (median } 4 \text { days). }\end{array}$ \\
\hline$\underset{* * *}{\mathrm{QRC}}$ & $\begin{array}{l}\text { Staiano } \\
2000\end{array}$ & Italy & Dietary fibre & $\begin{array}{l}\text { Randomly assigned to } \\
\text { double-blind treatment } \\
\text { with either glucomannan } \\
(n=10) \text { or placebo }(n= \\
\text { 10) for } 12 \text { weeks } \\
\text { following a } 2 \text { wk baseline } \\
\text { period. Before patients } \\
\text { entered the treatment } \\
\text { period, impacted feces } \\
\text { were removed with }\end{array}$ & $\begin{array}{l}\text { Children with severe } \\
\text { neurological damage } \\
\text { (brain damage due to } \\
\text { perinatal or prenatal } \\
\text { hypoxia) and chronic } \\
\text { constipation (at least one } \\
\text { year duration) \& most } \\
\text { evacuation not possible } \\
\text { without enema. All fed } \\
\text { semi-liquid diet by mouth }\end{array}$ & 20 & $\begin{array}{l}\text { ns } \\
\text { (5.7 (4.2); ns) }\end{array}$ & 74 & $\begin{array}{l}\text { Symptoms, stool } \\
\text { habits, } \\
\text { gastrointestinal } \\
\text { transit times, } \\
\text { anorectal } \\
\text { motility, laxative } \\
\& \text { suppository } \\
\text { use. }\end{array}$ & $\begin{array}{l}1 \text { child withdrew leaving } 10 \text { placebo, } 9 \text { glucomannan. No side effects } \\
\text { reported, and treatment well-tolerated in both groups. After } 12 \text { weeks } \\
\text { of treatment, glucomannan significantly increased stool frequency } \\
\text { from } 1.8 \pm 0.2 \text { stools/wk to } 3.8 \pm 0.9 \text { stools/wk }(p<.01 \text { ). Stool } \\
\text { frequency did not increase with placebo (from } 2.3 \pm 0.7 \text { stools/wk to } \\
2.0 \pm 0.6 \text { stools/wk). Laxative or suppository use significantly ( } p<.01 \text { ) } \\
\text { reduced by glucomannan (from } 1.9 \pm 1.3 \text { doses/wk to } 0.3 \pm 0.5 \\
\text { doses/wk) but not by placebo (from } 2.5 \pm 0.5 \text { doses/wk to } 2.1 \pm 0.4 \\
\text { doses/wk). Clinical scores of stool consistency were significantly } \\
\text { improved and episodes of painful defecation per week were }\end{array}$ \\
\hline
\end{tabular}




\begin{tabular}{|c|c|c|c|c|c|c|c|c|c|c|}
\hline $\begin{array}{l}\text { MMAT } \\
\text { Type \& } \\
\text { Rating }\end{array}$ & $\begin{array}{l}\text { 1st Author } \\
\& \\
\text { Year }\end{array}$ & Country & $\begin{array}{l}\text { Management } \\
\text { Related Focus }\end{array}$ & Design & $\begin{array}{l}\text { Key sample features } \\
\text { (age group; setting) }\end{array}$ & $\begin{array}{r}\text { Sample } \\
\text { size }\end{array}$ & $\begin{array}{l}\text { Age range } \\
\text { (mean (SD); } \\
\text { median) }\end{array}$ & $\begin{array}{r}\% \\
\text { male }\end{array}$ & $\begin{array}{l}\text { Outcome } \\
\text { measures }\end{array}$ & Management Related Results \\
\hline & & & & $\begin{array}{l}\text { repeated enemas for } 2 \\
\text { or } 3 \text { days. }\end{array}$ & (child; ns) & & & & & $\begin{array}{l}\text { significantly reduced by glucomannan }(p<.01) \text { but not by placebo. } \\
\text { However, neither glucomannan nor placebo had a measurable effect } \\
\text { on total and segmental transit times. Glucomannan improves stool } \\
\text { frequency but had no effect on colonic motility. }\end{array}$ \\
\hline$\underset{* *}{\text { QNR }}$ & $\begin{array}{l}\text { Tse } \\
2000\end{array}$ & $\begin{array}{l}\text { Hong } \\
\text { Kong }\end{array}$ & $\begin{array}{l}\text { Fibre intake \& } \\
\text { effect of } \\
\text { increasing fibre } \\
\text { intake on } \\
\text { laxative use }\end{array}$ & $\begin{array}{l}\text { Pilot study. Dietary } \\
\text { intake assessed over } 3 \\
\text { days. Within subjects } \\
\text { repeated measures to } \\
\text { look at effect of adding } \\
\text { fibre to diet. All-Bran } \circledast \\
\text { added in breakfast: } \\
\text { stage } 1=20 \text { days } 17 \mathrm{~g} \\
\text { fibre; (followed by } 10 \text { day } \\
\text { normal diet); stage } 2=6 \\
\text { weeks } 21 \mathrm{~g} \text { fibre }\end{array}$ & $\begin{array}{l}\text { Children with severe } \\
\text { developmental } \\
\text { disabilities in large } \\
\text { residential institution, } \\
\text { orally fed, medically } \\
\text { stable } \\
\text { (child; institution) }\end{array}$ & 20 & $\begin{array}{l}3-17 \\
\text { (ns (ns); ns) }\end{array}$ & ns & $\begin{array}{l}\text { BMs and the } \\
\text { number of } \\
\text { laxatives used } \\
\text { recorded } \\
\text { throughout study } \\
\text { (however results } \\
\text { do not mention } \\
\text { BM just } \\
\text { laxatives) }\end{array}$ & $\begin{array}{l}\text { Baseline fibre intake very low at around } 2 \mathrm{~g} / \text { day. Mean number of } \\
\text { laxatives required per week per child decreased significantly from a } \\
\text { baseline value of } 1.22 \text { (about } 5 \text { laxatives/month) (SD } 0.36 \text { ) to } 0.90 \\
\text { (about } 3.5 \text { laxatives/month) (SD 0.75) in the first stage, and } 0.71 \\
\text { (about } 3 \text { laxatives/month) (SD 0.40) in the second stage. No } \\
\text { significant difference between the two stages of fibre supplementation } \\
\text { (17 g versus } 21 \mathrm{~g} \text { ). }\end{array}$ \\
\hline$\underset{* * *}{Q D}$ & $\begin{array}{l}\text { Böhmer } \\
2001\end{array}$ & $\begin{array}{l}\text { Nether- } \\
\text { lands }\end{array}$ & $\begin{array}{l}\text { Frequency and } \\
\text { type of laxatives; } \\
\text { manual } \\
\text { evacuation of } \\
\text { faeces }\end{array}$ & $\begin{array}{l}\text { Prospective collection of } \\
\text { daily data by nursing } \\
\text { staff }\end{array}$ & $\begin{array}{l}\text { People with ID with IQ < } \\
50 \text { (moderate to } \\
\text { profound ID) from } 4 \\
\text { institutions } \\
\text { (adult \& child (\% ns); } \\
\text { institutions) }\end{array}$ & 215 & $\begin{array}{l}6-80 . \\
\text { Constipation } \\
\text { group } 31.8 \\
\text { (15.8); ns. } \\
\text { Not } \\
\text { constipated } \\
\text { group 34.1 } \\
\text { (18.6); ns }\end{array}$ & 60 & $\begin{array}{l}\text { Frequency \& } \\
\text { type of laxative; } \\
\text { use of manual } \\
\text { evacuation }\end{array}$ & $\begin{array}{l}\text { Of } 149(69.3 \%) \text { with constipation, } 57.6 \% \text { used bisacodyl (S) or } \\
\text { magnesium oxide (0), } 38.6 \% \text { used lactulose }(0), 13.4 \% \text { used sodium } \\
\text { lauryl sulphoacetate/sodium citrate/sorbitol }(0) \text { and } 9.6 \% \text { used sodium } \\
\text { phosphate enemas }(0) .51(34.2 \%) \text { used two of the above in } \\
\text { combination, and } 14(9.4 \%) \text { used } 3 \text { of the above in combination. } \\
\text { Manual evacuation of faeces by nurses in } 10 \text { patients }(6.7 \%) \text {. There } \\
\text { was a high frequency and variety in laxative treatment with variable } \\
\text { efficacy. }\end{array}$ \\
\hline$\underset{*}{Q}$ & $\begin{array}{l}\text { Emly } \\
2001\end{array}$ & England & $\begin{array}{l}\text { Nursing team } \\
\text { perspective of } \\
\text { abdominal } \\
\text { massage }\end{array}$ & $\begin{array}{l}\text { Audit took place } 18 \\
\text { months after introduction } \\
\text { of abdominal massage } \\
\text { for clients unsuccessfully } \\
\text { managed on laxatives. } \\
\text { Questionnaire with } 10 \\
\text { open-ended questions }\end{array}$ & $\begin{array}{l}4 \text { RNMHs, } 6 \text { healthcare } \\
\text { workers involved in } \\
\text { implementation of } \\
\text { abdominal massage } \\
\text { programme in NHS } \\
\text { group home } \\
\text { (staff supporting adults; } \\
\text { community home) }\end{array}$ & 10 & ns & ns & $\begin{array}{l}\text { Responses to } 10 \\
\text { open ended } \\
\text { questions }\end{array}$ & $\begin{array}{l}\text { There was a change in clinical practice and staff attitudes to bowel } \\
\text { management, increasing commitment to the change in practice, } \\
\text { increased confidence \& knowledge of bowel care. More aware of } \\
\text { faecal impaction risk. Initial anxieties on the withdrawal of laxatives } \\
\text { unfounded. Greater emphasis on diet, fluid intake, exercise and } \\
\text { passive movement. }\end{array}$ \\
\hline$\underset{* *}{\mathrm{QD}}$ & $\begin{array}{l}\text { Dickson } \\
2002\end{array}$ & Scotland & $\begin{array}{l}\text { Diet \& bowel } \\
\text { management } 4 \\
\text { years after move } \\
\text { from hospital to } \\
\text { community; staff } \\
\text { training }\end{array}$ & $\begin{array}{l}\text { Retrospective analysis of } \\
\text { records \& cross- } \\
\text { sectional semi-structured } \\
\text { interview with staff on } \\
\text { duty at time of data } \\
\text { collection }\end{array}$ & $\begin{array}{l}\text { People with ID who had } \\
\text { moved from a hospital to } \\
\text { staffed homes } 4 \text { years } \\
\text { previously, } 45.5 \% \text { non- } \\
\text { ambulant } \\
\text { (adult; community } \\
\text { homes) }\end{array}$ & 44 & $\begin{array}{l}\text { ns } \\
\text { (49.5 (10.9); } \\
\text { ns) }\end{array}$ & 61 & $\begin{array}{l}\text { Previous \& } \\
\text { current } \\
\text { medication for } \\
\text { bowel } \\
\text { management }\end{array}$ & $\begin{array}{l}12 / 44 \text { received no bowel medication. Since moving to community, } 14 \\
(32 \%) \text { had some decrease in bowel medication, } 9(20 \%) \text { an increase. } \\
\text { Age, gender, ambulancy, input from dietician, receiving special diet or } \\
\text { deciding own diet not associated with changes in bowel medication. } \\
\text { Increase in medication associated with support by staff with no } \\
\text { training. Decrease in medication associated with support by staff with } \\
\text { training. } 41 / 44 \text { support staff decided on diet. } 0 / 44 \text { received input from } \\
\text { clinical psychology for behavioural management in relation to bowel } \\
\text { control. } 18(41 \%) \text { of staff had any training in relation to diet and/or } \\
\text { bowel management, } 16 \text { of whom received a half-day course on basic }\end{array}$ \\
\hline
\end{tabular}




\begin{tabular}{|c|c|c|c|c|c|c|c|c|c|c|}
\hline $\begin{array}{l}\text { MMAT } \\
\text { Type \& } \\
\text { Rating }\end{array}$ & $\begin{array}{l}\text { 1st Author } \\
\& \\
\text { Year }\end{array}$ & Country & $\begin{array}{l}\text { Management } \\
\text { Related Focus }\end{array}$ & Design & $\begin{array}{l}\text { Key sample features } \\
\text { (age group; setting) }\end{array}$ & $\begin{array}{r}\text { Sample } \\
\text { size }\end{array}$ & $\begin{array}{l}\text { Age range } \\
\text { (mean (SD); } \\
\text { median) }\end{array}$ & $\begin{array}{r}\% \\
\text { male }\end{array}$ & $\begin{array}{l}\text { Outcome } \\
\text { measures }\end{array}$ & Management Related Results \\
\hline & & & & & & & & & & $\begin{array}{l}\text { nutrition from dietician. } 1 \text { had training relating to gastrostomy tube } \\
\text { feeding, } 1 \text { eating, drinking, swallowing difficulty. No association } \\
\text { between staff training \& whether clients on bowel medication. }\end{array}$ \\
\hline QNR & $\begin{array}{l}\text { Migeon- } \\
\text { Duballet } \\
2006\end{array}$ & France & $\begin{array}{l}\text { Long-term } \\
\text { efficacy, safety } \\
\text { and cost- } \\
\text { effectiveness of } \\
\text { PEG } 3350 \text { plus } \\
\text { electrolytes } \\
\text { (PEG+E) }\end{array}$ & $\begin{array}{l}\text { Retrospective analysis of } \\
\text { records \& hospital } \\
\text { pharmacy records. } \\
\text { Participants treated with } \\
\text { with PEG+E (1-3 } \\
\text { sachets a day) for } 24 \\
\text { months. Data compared } \\
\text { with that of } 21 \text { months } \\
\text { preceding PEG } \\
\text { introduction }\end{array}$ & $\begin{array}{l}\text { Residents at specialist } \\
\text { unit with severe } \\
\text { intellectual \& physical } \\
\text { disability; less than one } \\
\text { stool per } 48 \mathrm{~h} \text { and/or } \\
\text { evacuation problems; } \\
\text { receiving laxatives } \\
\text { (adults (ns - assumed); } \\
\text { institution) }\end{array}$ & $\begin{array}{r}54 \\
\text { (pre- } \\
P E G+E \\
\text { control } \\
\text { data for } \\
16 / 54 \text { ) }\end{array}$ & $\begin{array}{l}\text { ns } \\
(36.1(11.9) ; \\
n s)\end{array}$ & 56 & $\begin{array}{l}\text { Number of stools } \\
\text { per month, } \\
\text { episodes of } \\
\text { diarrhoea, } \\
\text { weight, } \\
\text { haematology and } \\
\text { blood } \\
\text { biochemistry, } \\
\text { monthly use \& } \\
\text { costs of } \\
\text { laxatives, } \\
\text { enemas \& } \\
\text { suppositories }\end{array}$ & $\begin{array}{l}\text { Mean number of stools per patient per month increased significantly } \\
\text { from } 12.4 \text { (SD 3.4) to } 24.9 \text { (SD 6.3), episodes of diarrhoea increased } \\
\text { significantly from } 0.1 \text { (SD 0.1) to } 6.3 \text { (SD 2.9), not associated with } \\
\text { adverse effects on body weight or blood biochemistry values, total } \\
\text { cost of laxatives per medical ward per year decreased from } 3788.17 \\
\text { to } 1767.39 \text { Euros after PEG+E }\end{array}$ \\
\hline$\underset{* *}{Q D}$ & $\begin{array}{l}\text { Marsh } \\
2008\end{array}$ & Ireland & $\begin{array}{l}\text { Registered } \\
\text { nurses' (RNs) } \\
\text { knowledge of } \\
\text { constipation in } \\
\text { people with ID }\end{array}$ & $\begin{array}{l}\text { Survey using self } \\
\text { completion questionnaire }\end{array}$ & $\begin{array}{l}\text { RNs supporting people } \\
\text { with ID. } 166 \mathrm{RNs} \\
\text { identified, } 59 \%(\mathrm{n}=98) \\
\text { response rate } \\
\text { (nurses in one ID health } \\
\text { service provider } \\
\text { supporting ns age; ns } \\
\text { settings) }\end{array}$ & 98 & ns & ns & $\begin{array}{l}\text { Number of } \\
\text { correct } \\
\text { responses to } 28 \\
\text { factual questions } \\
\text { (true/false/ } \\
\text { unsure) }\end{array}$ & $\begin{array}{l}\text { Overall accuracy of } 64 \% \text { suggests good overall knowledge in } \\
\text { prevention and management of constipation. Knowledge deficits } \\
\text { included: only } 64(65 \%) \text { correctly identified anticonvulsants as } \\
\text { increasing constipation; } 68(69 \%) \text { did not recognise diabetes as being } \\
\text { associated with constipation; and whilst } 81(83 \%) \text { recognised the } \\
\text { need for } 5 \text { daily portions of fruit or vegetables, } 65(66 \%) \text { correctly } \\
\text { identified } 2 \text { litres of fluid a day as a minimum recommendation. } 33 \% \\
\text { incorrectly identified the best position for having a BM as on the toilet } \\
\text { with feet hanging freely above the floor. }\end{array}$ \\
\hline QD & $\begin{array}{l}\text { van der } \\
\text { Heide } \\
2009\end{array}$ & $\begin{array}{l}\text { Nether- } \\
\text { lands }\end{array}$ & $\begin{array}{l}\text { Laxative } \\
\text { prescription }\end{array}$ & $\begin{array}{l}\text { Retrospective analysis of } \\
\text { medical \& pharmacy } \\
\text { records }\end{array}$ & $\begin{array}{l}\text { People with profound } \\
\text { intellectual and multiple } \\
\text { disabilities (PIMD) living } \\
\text { in } 8 \text { facilities for people } \\
\text { with ID } \\
\text { (adult } 93 \% \text {, child } 7 \% \text {; } \\
\text { institutions) }\end{array}$ & 254 & $\begin{array}{l}\text { 6-82 } \\
\text { (ns (ns); 49) }\end{array}$ & 46 & $\begin{array}{l}\text { Laxatives } \\
\text { prescribed in } \\
\text { prior } 12 \text { months }\end{array}$ & $\begin{array}{l}226(89 \%) \text { prescribed medication in prior } 12 \text { months. Most frequently } \\
\text { prescribed were laxatives (165/254, 65\%). Constipation was a } \\
\text { registered health problem in } 68 \%(\mathrm{n}=112 / 165 ; 95 \% \mathrm{Cl} 61-75 \%) \text { of } \\
\text { cases where laxative prescribed. Laxatives prescribed: macrogol } \\
\text { PEG) combinations (O) } 76 / 254(30 \%) \text {; bisacodyl (S) } 73 / 254(29 \%) ; \\
\text { lactulose (O) } 36 / 254(14 \%) ; \text { lactitol (O) } 31 / 254(12 \%) \text {; sodium } \\
\text { phosphate (enema) (O) } 25 / 254(10 \%) \text {; Isphagula (B) } 9 / 254(4 \%) \text {; } \\
\text { docusate sodium (enema) (S) } 7 / 254(3 \%) \text {; All medications prescribed } \\
\text { for five or less participants } 15 / 254(6 \%)\end{array}$ \\
\hline$\underset{* \text { Q }}{\text { Q }}$ & $\begin{array}{l}\text { Vuegelers } \\
2010\end{array}$ & $\begin{array}{l}\text { Nether- } \\
\text { lands }\end{array}$ & $\begin{array}{l}\text { Prevalence \& } \\
\text { clinical } \\
\text { presentation of } \\
\text { constipation }\end{array}$ & $\begin{array}{l}\text { Cross-sectional } \\
\text { observational study with } \\
\text { diary completion over } \\
\text { two weeks }\end{array}$ & $\begin{array}{l}\text { Children with severe } \\
\text { generalized CP \& ID, } \\
\text { most living at home } \\
\text { (child; family home } 80 \% \\
\text { (remainder ns)) }\end{array}$ & 152 & $\begin{array}{l}2-18 \\
(9.6(4.6) ; \mathrm{ns})\end{array}$ & 51 & $\begin{array}{l}\text { Laxative use, } \\
\text { fibre and fluid } \\
\text { intake }\end{array}$ & $\begin{array}{l}\text { Prevalence of constipation } 57 \%(95 \% \mathrm{Cl} 45 \%, 69 \%) \text {. Of the } 152 \\
\text { children, } 54.6 \% \text { used any laxative, } 13.2 \% \text { polyethylene glycol (O), } \\
24.3 \% \text { disaccharide (O), } 7.9 \% \text { other. Rectal laxative use } 22.4 \% \text {. } \\
\text { Manual disimpaction } 9.2 \% \text {. Of } 83 \text { children using laxatives, } 36 \% \\
\text { nonetheless showed symptoms of constipation. Dietary intakes below } \\
\text { the recommended amounts for water in } 86.5 \% \text { and in } 48 \% \text { of children } \\
\text { was more than } 500 \mathrm{~mL} \text { below the recommended daily minimum. Daily }\end{array}$ \\
\hline
\end{tabular}




\begin{tabular}{|c|c|c|c|c|c|c|c|c|c|c|}
\hline $\begin{array}{l}\text { MMAT } \\
\text { Type \& } \\
\text { Rating }\end{array}$ & $\begin{array}{l}\text { 1st Author } \\
\& \\
\text { Year }\end{array}$ & Country & $\begin{array}{l}\text { Management } \\
\text { Related Focus }\end{array}$ & Design & $\begin{array}{l}\text { Key sample features } \\
\text { (age group; setting) }\end{array}$ & $\begin{array}{r}\text { Sample } \\
\text { size }\end{array}$ & $\begin{array}{l}\text { Age range } \\
\text { (mean (SD); } \\
\text { median) }\end{array}$ & $\begin{array}{r}\% \\
\text { male }\end{array}$ & $\begin{array}{l}\text { Outcome } \\
\text { measures }\end{array}$ & Management Related Results \\
\hline & & & & & & & & & & $\begin{array}{l}\text { intake of fibre was below recommended amounts in } 53.2 \% \text {, more than } \\
6 \mathrm{~g} \text { below the recommended minimum in } 41 \% \text {, and } 6 \text { children (all tube } \\
\text { fed) received no fibre at all. However, no significant relation between } \\
\text { fibre or water intake and constipation was found. }\end{array}$ \\
\hline$\underset{*}{\text { QNR }}$ & $\begin{array}{l}\text { Bromley } \\
2014\end{array}$ & England & $\begin{array}{l}\text { Abdominal } \\
\text { massage }\end{array}$ & $\begin{array}{l}\text { Service development } \\
\text { initiative with pre/post } \\
\text { data collection. Parents } \\
\text { trained \& asked to } \\
\text { complete abdominal } \\
\text { massage for } 20 \text { mins a } \\
\text { day and recorded } \\
\text { outcomes over } 6 \text { week } \\
\text { period }\end{array}$ & $\begin{array}{l}\text { All had physical disability } \\
\text { and learning disabilities } \\
\text { or complex needs and } \\
\text { chronic constipation (>8 } \\
\text { weeks) } \\
\text { (child; family home) }\end{array}$ & 25 & $\begin{array}{l}\text { ns (inclusion } \\
\text { criteria age } 3 \\
\text { mths to } 19 \\
\text { yrs) }\end{array}$ & ns & $\begin{array}{l}\text { Bristol stool chart } \\
\text { (consistency), } \\
\text { frequency BM, } \\
\text { perceived } \\
\text { improvement in } \\
\text { service use \& } \\
\text { quality of life, } \\
\text { laxative use }\end{array}$ & $\begin{array}{l}\text { Results report a wide range of quality of life improvements including } \\
\text { relief in symptoms of constipation ( } 87.5 \%) \text {, reduction in laxative } \\
\text { medication (58\%), improved dietary intake }(41 \%) \text {, improved sleep } \\
\text { pattern } 37 \% \text {. Qualitative data indicate positive experiences described } \\
\text { by parents which include enhanced parent-child relationships. } \\
\text { Optimal stool type } 4 \text { increased from } 13 \text { to } 59 \% \text {. Annual cost saving } \\
\text { for } 10 \text { who had reduced laxative use estimated to be } £ 1,322.03 \text {. Cost } \\
\text { of education/training estimated to be } £ 35.20 \text { per family }\end{array}$ \\
\hline$\underset{* *}{Q D}$ & $\begin{array}{l}\text { Connor } \\
2014 \\
\text { (part I) }\end{array}$ & England & $\begin{array}{l}\text { Audit of bowel } \\
\text { care }\end{array}$ & Audit & $\begin{array}{l}\text { People with ID living in } \\
\text { care homes in one trust } \\
\text { area } \\
\text { (age ns; community care } \\
\text { homes) }\end{array}$ & 181 & ns & ns & $\begin{array}{l}\text { Number \& type } \\
\text { of laxatives }\end{array}$ & $\begin{array}{l}\text { The audit included } 181 \text { residents, of whom } 65(36 \%) \text { taking laxatives } \\
\text { every day. } 32 \text { took one laxative (none of whom had enemas and/or } \\
\text { suppositories), } 20 \text { took } 2 \text { ( } 3 \text { of whom had enemas and/or } \\
\text { suppositories), } 10 \text { took } 3 \text { ( } 4 \text { of whom had enemas and/or } \\
\text { suppositories) and } 3 \text { took more than } 3 \text { laxatives (for all of whom this } \\
\text { included enemas and/or suppositories). Laxatives taken (and type) } \\
\text { were: lactulose (O) n=46; senna (S) } 27 \text {; fybogel (B) 13; bisocodyl } \\
\text { suppositories (S) } 8 \text {; movicol (macrogol/PEG) (O) } 4 \text {; husk (B) } 2 \text {; } \\
\text { glycerin suppositories (O) 2; bisocodyl (oral) (S) } 1 \text {; microlax enema } \\
\text { (O) } 1 \text {; unspecified enema 1. }\end{array}$ \\
\hline Q & $\begin{array}{l}\text { Connor } \\
2014 \\
\text { (part II) }\end{array}$ & England & $\begin{array}{l}\text { Parent/carer } \\
\text { feedback on } \\
\text { abdominal } \\
\text { massage }\end{array}$ & $\begin{array}{l}\text { Questionnaire sent to } \\
\text { families and carers to } \\
\text { identify positive and } \\
\text { negative aspects of } \\
\text { abdominal massage } \\
\text { implemented as part of a } \\
\text { total bowel management } \\
\text { programme }\end{array}$ & $\begin{array}{l}\text { Parents/carers involved } \\
\text { in abdominal massage } \\
\text { (carers of adults \& } \\
\text { children (\% ns); } \\
\text { community based) }\end{array}$ & ns & ns & ns & $\begin{array}{l}\text { Open ended } \\
\text { comments on } \\
\text { use of abdominal } \\
\text { massage }\end{array}$ & $\begin{array}{l}\text { All feedback on the introduction of abdominal massage was positive, } \\
\text { including comments regarding: ease of learning \& implementation; } \\
\text { bowel movement changes; improvements in pain, mood or behaviour; } \\
\text { reduction of laxatives. No negative responses received. Some } \\
\text { reported that adopting abdominal massage provided further } \\
\text { opportunity to develop the therapeutic relationship. Positive case } \\
\text { studies ( } n=4) \text { also given of introduction of massage. }\end{array}$ \\
\hline QD & $\begin{array}{l}\text { Joos } \\
2016\end{array}$ & Belgium & $\begin{array}{l}\text { Medication used } \\
\text { by people with ID } \\
\text { with enteral } \\
\text { feeding tube } \\
\text { (EFT) }\end{array}$ & $\begin{array}{l}\text { Cross-sectional } \\
\text { observational study } \\
\text { using medication records }\end{array}$ & $\begin{array}{l}92.3 \% \text { profound ID, all } \\
\text { with EFT \& receiving } \\
\text { chronic medication } \\
\text { through EFT, living in } \\
\text { residential care facilities } \\
\text { (adult \& child (\% ns); } \\
\text { institution) }\end{array}$ & 156 & $\begin{array}{l}2-80 \\
\text { (ns (ns); 20) }\end{array}$ & 41 & $\begin{array}{l}\text { Medication } \\
\text { administered } \\
\text { through EFT }\end{array}$ & $\begin{array}{l}75 \% \text { used drugs for constipation ( } 2^{\text {nd }} \text { most frequent after antiepileptics } \\
\text { at } 78.2 \%) .2^{\text {nd }} \text { most common chronic drug used was macrogol (PEG) } \\
\text { combinations }(0)(48.1 \% \text { of } 156 \text { participants). Other laxatives noted } \\
\text { were lactulose }(0)(n=24) \text {, sorbitol }(0)(n=21) \text {. }\end{array}$ \\
\hline
\end{tabular}


Abbreviations: BM bowel movement; CP cerebral palsy; EFT enteral feeding tube; ID intellectual disability; PEG polyethylene glycol; PEG+E polyethylene glycol 3350 plus electrolytes; ns not stated; NHS national health service; RNMH registered nurse (mental handicap). Laxative types: B bulk forming; O osmotic; S stimulant. MMAT types: Q qualitative; QRC quantitative randomized controlled (trial); QNR quantitative non-randomized; QD quantitative descriptive. 